\title{
Implementing the United Nations' Sustainable Development Goals in international business
}

\author{
Ivan Montiel ${ }^{1}$, Alvaro Cuervo- \\ Cazurra ${ }^{2}$, Junghoon Park', \\ Raquel Antolín-López ${ }^{3}$ and \\ Bryan W. Husted ${ }^{4}$
}

\author{
${ }^{1}$ Zicklin School of Business, Baruch College, The \\ City University of New York, 55 Lexington Ave at \\ 24th Street, New York, NY 10010, USA; \\ ${ }^{2}$ D'Amore-McKim School of Business, \\ Northeastern University, 313 Hayden Hall, 360 \\ Huntington Avenue, Boston, MA 02115, USA; \\ ${ }^{3}$ Department of Economics and Business \\ Administration, University of Almeria, Ctra. \\ Sacramento $s / n$, \\ 04120 La Cañada de San Urbano, Almería, Spain; \\ ${ }^{4}$ EGADE Business School, Tecnológico de \\ Monterrey, Eugenio Garza Lagüera \& Rufino \\ Tamayo, Valle Oriente, \\ 66269 San Pedro Garza García, Nuevo León, \\ Mexico
}

Correspondence:

I Montiel, Zicklin School of Business, Baruch College, The City University of New York, 55 Lexington Ave at 24th Street, New York, NY 10010, USA

e-mail: ivan.montiel@baruch.cuny.edu

\begin{abstract}
Building on the concept of externalities, we propose an explanation of how multinationals can contribute to the enactment of the United Nations' Sustainable Development Goals as part of their ordinary investments. First, we suggest grouping the 17 Sustainable Development Goals into six categories based on whether they increase positive externalities - knowledge, wealth, or health - or reduce negative externalities - the overuse of natural resources, harm to social cohesion, or overconsumption. Second, we propose placing these categories within an extended value chain to facilitate their implementation. Third, we argue that multinationals' internal investments in host-country subsidiaries to improve their competitiveness contribute to addressing externalities in host-country communities, while external investments in host communities to solve underdevelopment generate competitiveness externalities on host-country subsidiaries.
\end{abstract}

Journal of International Business Studies (2021) 52, 999-1030.

https://doi.org/ I 0. I057/s41 267-021-00445-y

Keywords: externalities; international business; multinationals; grand challenges; Sustainable Development Goals (SDGs); sustainability

\begin{abstract}
At Grupo Nutresa, we understood that sustainability is the framework that encompasses the operation, that there is no profitable growth without integrating environmental or social issues. That's what makes an organization and its stakeholders gain or lose value. [...] This has been the result of deep discussions because, after all, when you start building your strategy with the SDGs, [you see] they are very intertwined. However, we asked ourselves where we can have a stronger positive influence on the SDGs, and how we really manage to contribute to the global agenda.
\end{abstract}

Claudia Rivera, Sustainability Director of the Colombian food multinational Grupo Nutresa, interviewed on July 1, 2020

\section{INTRODUCTION}

Climate change, extreme poverty, and pandemics are all grand challenges, i.e., large intractable global problems that bedevil the world. The usual attitude in the face of these grand challenges is to ask governments to coordinate their actions and to collaborate in addressing them. This has resulted not only in the creation of
Received: 22 February 2020

Revised: 8 April 2021

Accepted: 10 April 2021

Online publication date: 25 May 2021 
intergovernmental organizations like the United Nations or the World Bank but also in programs within these organizations to focus attention on crucial issues. Thus, in 2015, the United Nations adopted the 2030 Agenda for Sustainable Development and established 17 Sustainable Development Goals (SDGs) for governments to achieve by 2030. This is considered one of the most effective plans of action to address pressing grand challenges (Kolk, Kourula, \& Pisani, 2017; Sachs, Schmidt-Traub, Mazzucato, Messner, Nakicenovic, \& Rockström, 2019; Salvia, Leal Filho, Brandli, \& Griebeler, 2019; van Zanten \& van Tulder, 2018). However, despite the increasing calls for management research to analyze grand challenges (George, Howard-Grenville, Joshi, \& Tihanyi, 2016) and critical issues (Tihanyi, 2020), and for international business research to rethink current agendas towards grand challenges (Buckley, Doh, \& Benischke, 2017), it is unclear how international business research can contribute to the SDGs, as they are designed as country-level goals for governments to achieve, not as firm-level goals. Although multinationals are increasingly rethinking their objectives and shifting from profit to value maximization (Business Roundtable, 2019) by embracing the SDGs (United Nations Global Compact \& Accenture, 2019), implementation is still incomplete (van Zanten \& van Tulder, 2018).

Hence, building on the concept of externalities, we propose an explanation of how multinationals can contribute to enacting the United Nations' SDGs as part of their ordinary investments. Specifically, we introduce three mechanisms for translating the country-level SDGs into firm-level actions. First, we suggest grouping the 17 SDGs into six categories based on whether they increase positive externalities (knowledge, wealth, or health) or reduce negative externalities (the overuse of natural resources, harm to social cohesion, or overconsumption). Second, we propose placing these categories within an extended value chain to facilitate their implementation. Third, we argue that multinationals' internal investments in host-country subsidiaries to improve their competitiveness contribute to addressing externalities in host-country communities, while external investments in host communities to solve underdevelopment generate competitiveness externalities in host-country subsidiaries.

These arguments contribute to two streams of international business research: corporate sustainability studies and theorization on multinational behavior. First, to the literature on global corporate sustainability, the paper offers a framework for making the SDGs actionable by multinationals. Sustainability is increasingly becoming a crucial topic in international business (Grinstein \& Riefler, 2015; Kim \& Davis, 2016; Kolk, 2010; Linnenluecke \& Griffiths, 2010; Maksimov, Wang, \& Yan, 2019; Pinkse \& Kolk, 2012; Shapiro, Hobdari, \& Oh, 2018; Yakovleva \& Vazquez-Brust, 2018). As part of their sustainability efforts, multinationals are increasingly embracing the SDGs in their corporate strategy (Donoher, 2017; Giuliani, Santangelo, \& Wettstein, 2016; Witte \& Dilyard, 2017), but these are limited actions that commonly focus on reducing negative effects (van Zanten \& van Tulder, 2018). We provide a prescriptive framework to help reduce the criticism that the SDGs are too abstract and numerous to elicit focused actions by firms (MacFeely, 2019; van Zanten \& van Tulder, 2018), so that multinationals can help create societal value in addition to profit. The prescriptive framework also offers guidance for researchers by providing an explanation of the mechanisms by which the SDGs can be implemented by multinationals through subsidiaries' investments. The propositions can be tested by future empirical studies analyzing multinational investments and SDGs.

Second, for the theorization on multinational behavior, we propose a reconsideration of some of the basic arguments by explicitly incorporating the role of externalities. Despite the importance of externalities in international business (Buckley, 2009; Buckley \& Ghauri, 2004), many theoretical models underplay them. A common approach is acknowledging unintended technological spillovers and how multinationals should aim to reduce them despite their positive impact on the host country (Blomström \& Kokko, 1998; Cantwell \& Piscitello, 2005; Castellani \& Zanfei, 2006; Das, 1987). However, large firms and multinationals can facilitate social value creation and the solution of externalities (Cuervo-Cazurra, 2018; Fisman \& Khanna, 2004; Rygh, 2019; Sinkovics \& Archieacheampong, 2019). We place externalities, both positive and negative, at the heart of our arguments. On the one hand, we explain how subsidiaries' investments to improve competitiveness have externalities that contribute to the implementation of SDGs in the host countries. On the other hand, we argue that multinationals' investments aimed to improve the context and address the SDGs have externalities on the subsidiaries. The explicit inclusion of the generation of positive externalities and the avoidance of negative ones changes 
predictions on internationalization decisions, helping reinvigorate international business research (Buckley, 2002; Buckley \& Lessard, 2005; Peng, 2004) by relaxing some of the assumptions of existing theories regarding value creation in multinationals. Integrating the SDGs within multinationals' objectives facilitates a move from shortterm economic value to long-term sustainable value, and offers a new view of the nexus between business and society in which multinationals become part of the solution to grand challenges rather than contributors to the problems.

\section{ADDRESSING GRAND CHALLENGES: THE SUSTAINABLE DEVELOPMENT GOALS}

The United Nations has spearheaded the coordination of activities for tackling grand challenges that affect humanity. A significant concerted effort identified the Millennium Development Goals in 2000 at the United Nations Millennium Declaration and established eight goals to achieve by 2015 (United Nations, 2000). The partial success of the Millennium Development Goals in transforming developing countries led to the creation of a more global agenda, the SDGs (Griggs, Stafford-Smith, Gaffney, Rockström, Öhman, Shyamsundar, Steffen, Glaser, Kanie, \& Noble, 2013). These were a call to end poverty, improve the lives of all, and protect the planet in the 2030 Agenda for Sustainable Development (United Nations, 2015). The SDGs expanded the 8 Millennium Development Goals to 17 goals to be achieved by 2030. The 17 SDGs are (United Nations, 2015): (1) No poverty; (2) Zero hunger; (3) Good health and well-being; (4) Quality education; (5) Gender equality; (6) Clean water and sanitation; (7) Affordable and clean energy; (8) Decent work and economic growth; (9) Industry, innovation, and infrastructure; (10) Reducing inequality; (11) Sustainable cities and communities; (12) Responsible consumption and production; (13) Climate action; (14) Life below water; (15) Life on land; (16) Peace, justice, and strong institutions; and (17) Partnerships for the goals. Unlike the Millennium Development Goals, which mainly targeted developing and underdeveloped countries, the SDGs explicitly call for a more balanced participation from advanced and developing nations, and acknowledge the important role played by the private sector.

Firms' contribution to the SDG agenda is challenging for two reasons. First, the extensive scope and complexity of the 17 SDGs, 169 targets, and 232 unique indicators easily overwhelm and prevent action (Easterly, 2015; Nilsson, Chisholm, Griggs, Howden-Chapman, McCollum, Messerli, Neumann, Stevance, Visbeck, \& Stafford-Smith, 2018). Second, there is a lack of a common understanding of how to operationalize the SDGs by firms because the SDGs are designed as countrylevel targets. Although the SDG Compass (Global Reporting Initiative, United Nations Global Compact, \& World Business Council for Sustainable Development, 2015) and the SDG Action Manager (B Lab \& United Nations Global Compact, 2020) provide tools for measuring and reporting on the SDGs, they leave it up to the firms to interpret how to integrate the SDGs into their operations.

Translating the SDGs for International Business: Value Chain, Externalities, and Investments

Hence, we propose a framework to help multinationals implement the SDGs. The framework builds on the concept of externalities as the theoretical driver of the translation of SDGs into multinationals' actions in three steps: (1) grouping of SDGs by their impact on the positive and negative externalities created by multinationals; (2) positioning of SDGs along the value chain; and (3) identifying how internal and external investments contribute to the SDGs and subsidiaries' competitiveness.

\section{Grouping the SDGs by their impact on externalities}

The first element in the framework is the grouping of SDGs into six broad categories depending on whether they enable the development of positive externalities (knowledge, wealth, and health) or help reduce negative externalities (the overuse of natural resources, harm to social cohesion, or overconsumption) as we illustrate in Figure 1. Externalities refer to situations in which third parties unwillingly bear costs or receive benefits from companies' actions (Ayres \& Kneese, 1969; Baumol, 1972). Externalities are classified as positive when third parties receive benefits from firm activities without paying for them; a typical example is technological spillover. Externalities are classified as negative when third parties suffer the costs of firm activities and are uncompensated for such costs; pollution is the classic example. Our conceptualization of externalities in the SDGs modifies the traditional views of reducing negative externalities for fear of punishment or limiting positive externalities for fear of losing advantage 

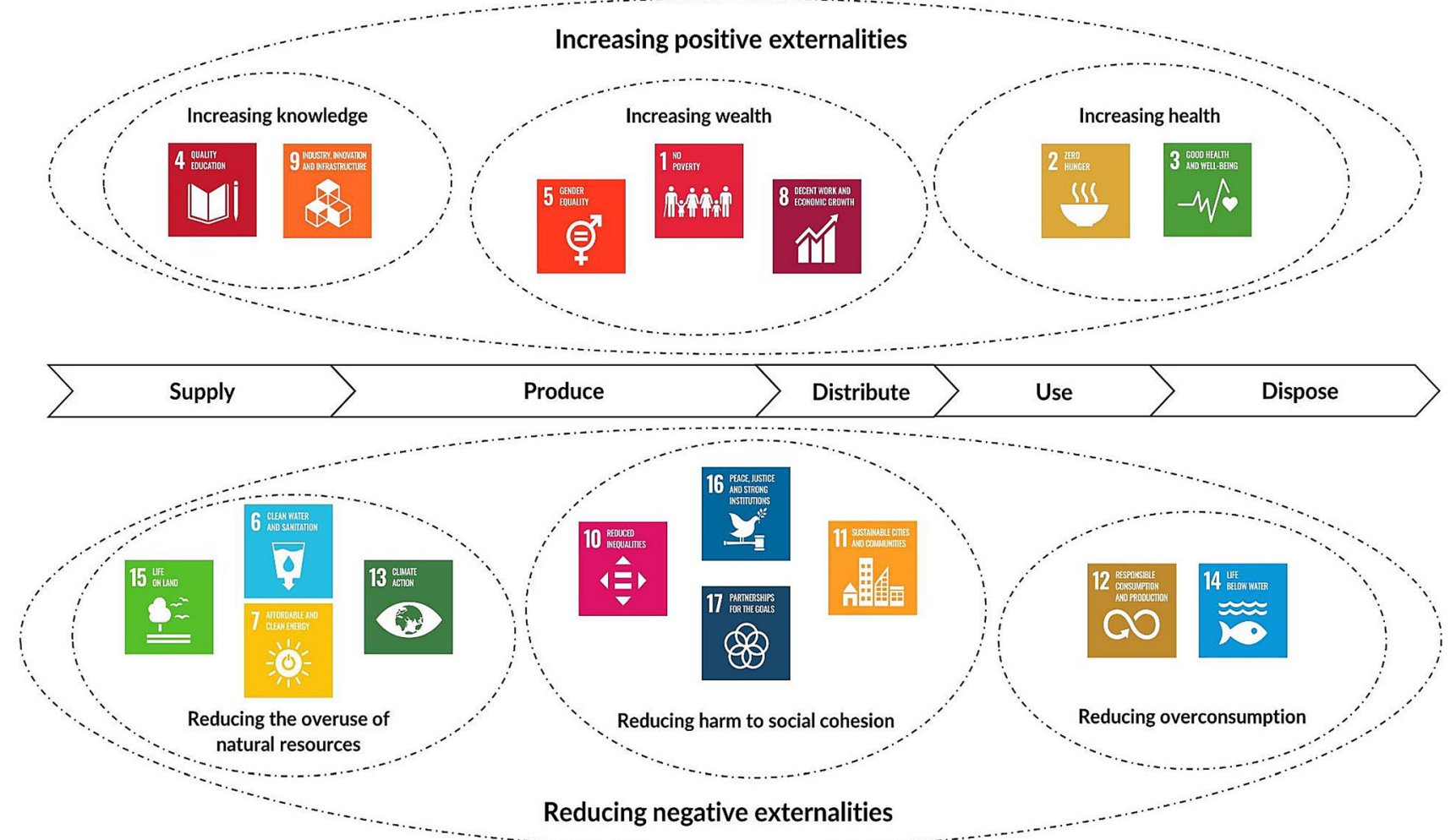

Figure 1 Translating SDGs into actionable goals for multinationals to address externalities. Note that the use of the SDG icons is permitted under the United Nations Department of Global Communications (United Nations, 2019).

discussed in previous research. Multinationals' efforts in addressing sustainability challenges have been driven by a desire to reduce negative externalities, especially for the environment, and the associated financial punishments and reputational harm in host countries (Jiang, Jung, \& Makino, 2020). The technological spillovers of multinationals in host countries through employee mobility, training of suppliers and distributors, and competitive imitation (Blomström \& Kokko, 1998; Cantwell \& Piscitello, 2005; Castellani \& Zanfei, 2006; Kano, 2018) are a form of positive externality, but the usual recommendation is for managers to reduce such positive spillovers (Buckley, 2009; Zhao, 2006).

\section{Positioning the SDGs in the value chain}

The second element for translating the countrylevel SDGs into concrete actions for multinationals is the value chain. The value chain is an economicsbased framework that classifies firms' activities into two main types (Porter, 1985): primary activities that directly enable the creation of value and secondary activities that support the primary activities. The primary activities were originally organized along an input-output chain as inbound logistics, operations, outbound logistics, marketing and sales, and service (Porter, 1985). The value chain has been refined and extended over time to incorporate the life cycle of products and services (Klöpffer, 1997). One of these refinements is the extended producer responsibility (Atasu \& Subramanian, 2012) that suggests five activities: supply, produce, distribute, use, and dispose. Hence, in Figure 1, we position the 17 SDGs along this extended value chain. We propose connecting the SDGs related to increasing knowledge to the supply and production activities: those linked to increasing wealth to the production and distribution activities; SDGs related to increasing health to the distribution, use, and disposal activities; SDGs associated with reducing the overuse of natural resources to the supply and production activities; those connected with reducing harm to social cohesion to the production, distribution, and use activities; and goals related to reducing overconsumption to the use and disposal activities. This 
approach clarifies the primary actions and investments that multinationals can take to address each goal.

\section{Identifying internal and external investments that contribute to the SDGs}

The third element of the framework is analyzing the multinationals' internal and external investments in host countries that enable the achievement of SDGs. We classify multinational investments into internal and external based on where they are made. On the one hand, internal investments are those made by the host-country subsidiary in primary stakeholders, i.e., stakeholders that have an explicit contractual relationship with the firm, like employees, suppliers, and distributors. We propose that these internal investments generate direct benefits for the multinational and have the potential to indirectly strengthen positive externalities or to reduce negative externalities in host-country communities, thus contributing to the SDG agenda. On the other hand, multinational external investments are those implemented in the host-country communities targeting secondary stakeholders, i.e., stakeholders that lack an explicit contractual relationship with the firm, such as local communities, the public at large, and interest groups; these investments are commonly made in collaboration with governments, non-governmental organizations, and transnational institutions. These external investments are designed to address externalities and directly contribute to the host-country SDG agenda as well as indirectly benefit multinationals.

Figure 2 summarizes the resulting framework and propositions. We first discuss how investments can contribute to positive externalities and then how they address negative externalities. In each case, we discuss the internal and external investments and illustrate the ideas with an extended example.

\section{Multinationals' Investments that Address the SDGs to Increase Positive Externalities}

We first argue that multinationals can design their investments and activities to contribute to the implementation of SDGs that strengthen positive externalities. Although appealing, this idea appears to counter theoretical arguments for limiting the firm's positive externalities to protect advantage or separating investments with high positive externalities from the firm's operations.

First, some scholars recommend that multinationals in host countries limit positive externalities in technology. Multinationals commonly bring more sophisticated technologies and innovations to the host country that eventually become diffused among local companies through unintended spillovers (Blomström \& Kokko, 1998; Blomström, Kokko, \& Mucchielli, 2003). Hence, multinationals' managers may design mechanisms that limit such diffusion to others because it undermines competitive advantage (Buckley, 2009; Zhao, 2006). Some of these mechanisms involve, for example, mitigating the investments provided to suppliers and distributors so that they do not upgrade their capabilities and become eventual competitors (Perri, Andersson, Nell, \& Santangelo, 2013), reasserting their strategic power to keep control over partners (Kano, 2018); establishing non-compete contracts that prevent employees from joining competitors for some time after leaving the firm to reduce spillovers via employee mobility (Aydinliyim, 2020; Garber, 2013; Nandkumar \& Srikanth, 2016); or building complexity and secrecy into the operation to reduce imitation (de Faria \& Sofka, 2010).

Second, multinationals typically invest in corporate social responsibility separately from the firms' core value chain activities, especially in the form of corporate philanthropy (Ite, 2004; Shah, 2013). A common corporate social responsibility approach is to invest in impactful activities in local communities in collaboration with not-for-profit organizations, because the latter have expertise in addressing local needs that multinationals lack (Dahan, Doh, Oetzel, \& Yaziji, 2010; Husted, 2003; Lev, Petrovits, \& Radhakrishnan, 2010; Newenham-Kahindi, 2011; Teegen, Doh, \& Vachani, 2004). These corporate social responsibility investments are usually separate from the activities of the company and managed independently from the firm's operations. In some cases, they are funded from the budget of the firm's foundation rather than from the general budget, since they are conceived as charitable contributions rather than investments (Husted, 2003; Lev et al., 2010). Multinationals report these investments in their corporate social responsibility reports, describing the actions and investments undertaken, the partner organizations with which they collaborate, and the apparent successes. Although many of these investments have substantial positive externalities, they are conceived and run separately from the company operations.

We propose integrating the SDGs within the value chain framework, thereby changing attitudes 


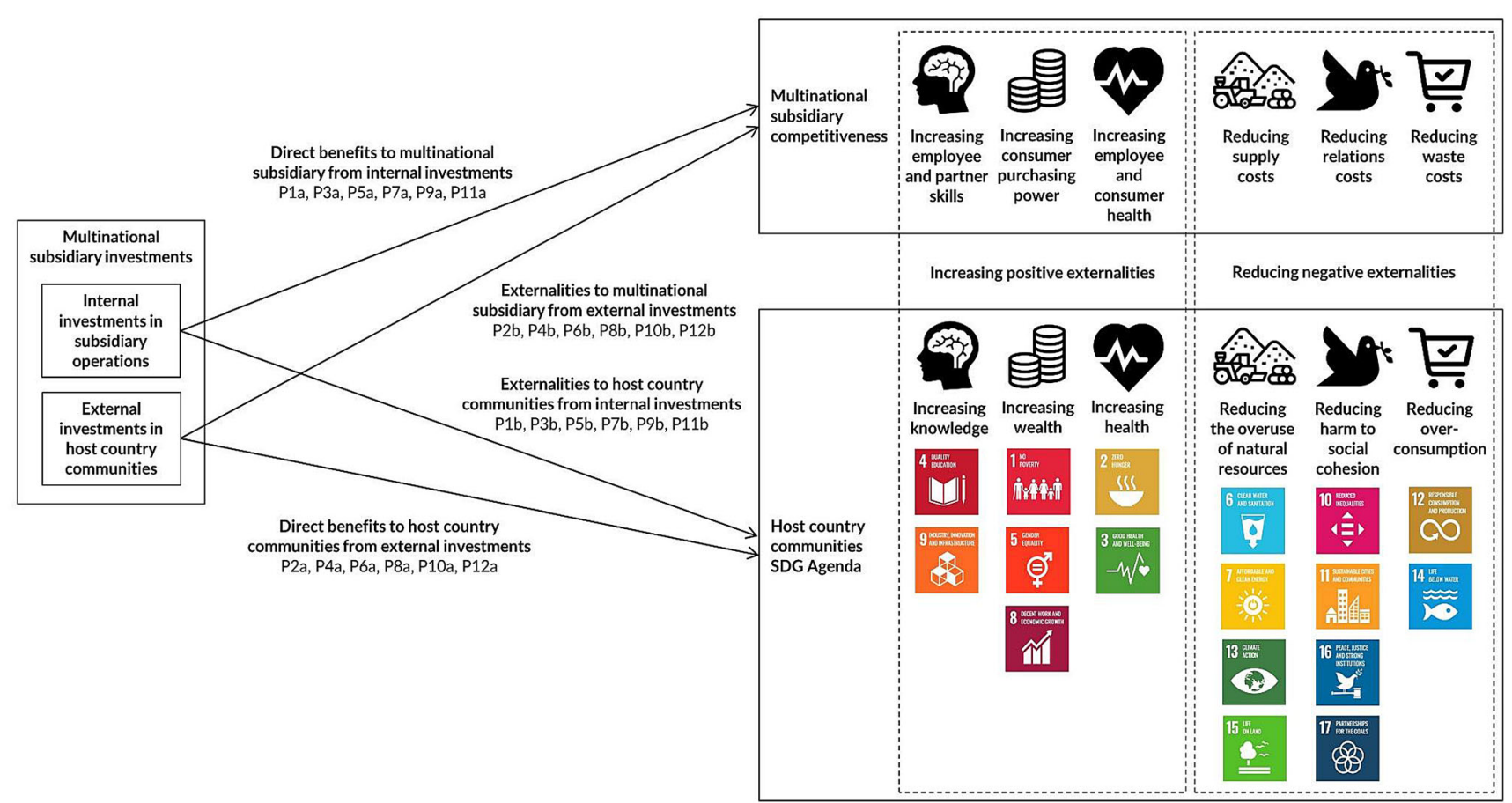

Figure 2 Multinational subsidiary investments and host-country communities SDG agenda. Note that the use of the SDG icons is permitted under the United Nations Department of Global Communications (United Nations, 2019). Use of the six icons representing each of the externalities is permitted by the Noun Project under a Creative Commons license.

towards positive externalities and how to invest to achieve them. Managers of multinationals can rethink how their internal investments improve local communities, aiming to expand and diffuse the positive externalities to the community. They can also redesign investments with a high impact on positive spillovers as an integral part of the firm's activities. In this way, investments in the multinationals' operations are evaluated in terms of the benefits provided to the multinational and the positive externalities that such investments bring to local communities (Rygh, 2019). This may lead multinationals to overinvest to facilitate the multiplier effect of the investments on the host-country population. Such investments may not generate an immediate financial return, but instead provide benefits in the long run through increased reputation and more robust social contracts with local communities that support future profitability.

To enable this investment, we propose grouping the SDGs that are likely to promote positive externalities into three main themes: increasing knowledge, increasing wealth, and increasing health. We suggest these groupings from the analysis of each of the goals and their similarity in the overarching topic.

\section{Multinationals' investments to increase knowledge}

Multinationals are well placed to have large positive externalities in creating knowledge in the host countries where they operate; their main source of advantage is their superior ability to create, transfer, and apply knowledge across countries (Kogut \& Zander, 1993). This knowledge generation and dissemination can foster positive externalities for SDG 4 "Quality education: Ensure inclusive and equitable quality education and promote lifelong learning opportunities for all", and SDG 9 "Industry, innovation, and infrastructure: Build resilient infrastructure, promote inclusive and sustainable industrialization and foster innovation." Addressing these goals is important. There are 57 million primary-age children out of school and 103 million youth who lack basic literacy skills, and more than $60 \%$ of them are female (United Nations Development Programme, 2020a). Four billion people do not have internet access, and $90 \%$ are in the developing world (United Nations Development Programme, 2020b).

Internal investments in knowledge capabilities in subsidiaries not only benefit a firm's competitiveness but can also be designed to have large positive externalities in the community and help achieve the 
SDGs. From a strategic standpoint, multinationals benefit more immediately from internal investments by working with more educated business partners and employees. Investments in knowledge capabilities in host-country subsidiaries can result not only in increasing labor productivity, income, value-added, and competitiveness within a supply chain (Birkinshaw, Hood, \& Jonsson, 1998; Strotmann, Volkert, \& Schmidt, 2019) but also in scaling-up their operations by securing sufficient local talent and improving talent management costs (Winthrop, Bulloch, Bhatt, $\&$ Wood, 2013). Investments in educating and training local value chain partners help improve their innovation capabilities and productivity (Kano, 2018; Wei \& Liu, 2006), as well as enhance their morale and retention (Farndale, Scullion, \& Sparrow, 2010; Reiche, 2008). At the same time, when multinationals build local human capital through employee training programs, and these highly skilled individuals may move to domestic firms or start their own business, thus creating positive knowledge spillovers (Fosfuri, Motta, \& Rønde, 2001; Gershenberg, 1987). The co-development of innovation with suppliers can help the multinational obtain better services from them (Dyer, 2000). Their upgraded capabilities enable suppliers and distributors to serve other companies and train their own suppliers and distributors about superior management practices, thus further contributing to responsible innovation, education, and industry development.

We summarize these arguments in the following propositions:

Proposition 1a: Multinational knowledge investments in a host-country subsidiary (e.g., implementing educational and training programs for employees, transferring technology to suppliers and distributors) have a positive impact on the subsidiary's competitiveness (more educated employees and more innovative business partners).

Proposition 1b: Multinational knowledge investments in a host-country subsidiary (e.g., implementing educational and training programs for employees, transferring technology to suppliers and distributors) create positive education externalities that contribute to the host-country SDG agenda [increasing local education (SDG 4) and innovativeness (SDG 9)].

External knowledge investments designed to develop a local community's knowledge base and contribute to the SDGs can also benefit the multinational. Multinationals work with selective external partners, such as local non-governmental organizations, governmental agencies, or other civil society organizations, and support their efforts to increase knowledge by donating funds for investments in education. To establish the most beneficial educational programs, multinationals usually engage with local partners to identify the primary educational deficiencies in the region and how to tackle them, collaborating in building schools and other educational infrastructure, such as scholarship programs in the host country (Eweje, 2006). Such investments also have a positive knowledge spillover for the firm, since well-educated and innovative local communities will be more sophisticated and innovative business partners and employees for the firm. The external investments in innovation can also boost current employees' commitment as they see themselves working for a firm that supports local communities (Brammer, Millington, \& Rayton, 2007).

We therefore present the following propositions:

Proposition 2a: Multinational knowledge investments in host-country communities (e.g., building local educational infrastructure, granting scholarships in local communities) have a positive impact on the host-country SDG agenda [increasing local education (SDG 4) and innovativeness (SDG 9)].

Proposition 2b: Multinational knowledge investments in host-country communities (e.g., building local educational infrastructure, granting scholarships in local communities) generate positive education externalities for the subsidiary (securing future access to qualified talent, increasing employee motivation and commitment).

An illustration of a multinational engaged in increasing knowledge externalities globally is the Spanish financial services company, BBVA, which is the second-largest bank in Spain and among the top 50 largest in the world, with a strong presence in Latin America. BBVA sees "education to be the best vehicle for bringing the age of opportunity to even the most vulnerable" (BBVA, 2019a), and has invested in international social educational programs that have benefitted more than 2.3 million people worldwide.

One of the internal investments used by BBVA to increase knowledge is the Hope Fund program in Chile. Hope Fund trains and supports BBVA's clients who are already microentrepreneurs and need financial support, assisting more than 120,000 
clients by 2020. BBVA also has an extensive digital training system, the Campus BBVA platform. This online training platform became especially valuable during the first 48 days of the COVID-19 confinement, where the platform saw a $450 \%$ jump in digital training with more than 1.2 million hours completed (BBVA, 2020). These programs have the potential to increase BBVA's competitiveness in its host-country operations by improving its employees' and business partners' knowledge skills and, therefore, its firm performance.

BBVA also engages in external investments in local communities devoted to education access, education quality, and financial education. On education access, BBVA provides scholarships to children, young people, and adults who would otherwise not have access to education. Since 2007, their Kids Ahead scholarship program to facilitate access for boys and girls in vulnerable situations has granted more than 720,000 scholarships in Mexico, Colombia, Paraguay, Peru, Uruguay, and Venezuela. On education quality, BBVA promotes social innovation in education and builds on teachers' skills by delivering training initiatives, knowledge-building, increasing visibility, creating networks, and developing free audiovisual pedagogical content for families and teachers worldwide. For instance, BBVA's Entrepreneurship School in Colombia has provided financial education to more than 190,000 students and 1090 teachers from 420 schools (BBVA, 2019b). In terms of fostering innovation, BBVA has also pledged investments, most of them towards accelerating digital transformation. Based on these external investments, BBVA expects to contribute to the SDG agenda by increasing local knowledge, as stated in their Pledge 2025 (BBVA, 2018).

To manage all these programs successfully and to increase positive impact, BBVA often collaborates with business associations, foundations, non-governmental organizations, local governments, and even other multinationals, like the Spanish telecommunications multinational Telefonica. For example, in Mexico, BBVA launched a collaboration with the local startup, Openpay, which offered a wide range of payment solutions and advanced online functionalities to shops and retailers, and was subsequently acquired by BBVA. Such innovation-collaboration programs aim to contribute to the SDG agenda by increasing innovation and generating positive knowledge spillovers for the multinational, when the company can access more educated and innovative talent, which enhances the subsidiary's competitiveness.

\section{Multinationals' investments to increase wealth}

Multinationals, as large organizations operating and controlling resources across borders, can increase wealth that will reduce inequalities in their host countries. Three interconnected SDGs relate to the positive externality of increasing wealth: SDG 1 "No Poverty: End poverty in all its forms everywhere;" SDG 5 "Gender equality: Achieve gender equality and empower all women and girls;" and SDG 8 "Decent work and economic growth: Promote sustained, inclusive and sustainable economic growth, full and productive employment and decent work for all." These three SDGs are interconnected. Job opportunities tackle poverty directly, especially among women, who in 2020 still have not reached economic equality anywhere globally and, therefore, are more likely to be poor (Oxfam, 2020). Gender seems to exacerbate inequality. By 2014, 143 countries included gender equality in their Constitution, but 52 countries did not (United Nations, 2018), and, by 2018 , working women were still making $20 \%$ less than men worldwide (Belser, Vazquez-Alvarez, \& $\mathrm{Xu}, 2018)$. Although the world has made significant progress in reducing extreme poverty - i.e., people living on less than USD1.90 a day - from 1.9 billion people or $36 \%$ of the world's population in 1990 to 734 million or $10 \%$ in 2015 , the 2020 COVID-19 pandemic reversed this trend and extreme poverty has risen, and almost half of the world population still lives on less than USD5.5 a day or USD2000 a year (World Bank, 2020).

Multinationals' internal investments in subsidiaries, such as implementing local hiring programs that provide decent work conditions and benefits, can help the subsidiaries be more competitive while contributing to societal advancement. Multinationals can embrace a diverse workforce in terms of gender and ethnicity (Ferner, Almond, \& Colling, 2005), improving working conditions in their host-country operations and among business partners across their global value chains, where they exercise indirect control. Multinationals can also prevent irresponsible practices, such as child exploitation (Kolk \& van Tulder, 2004), sweatshop conditions (Radin \& Calkins, 2006), or modern slavery (Burmester, Michailova, \& Stringer, 2019), by forbidding them as part of their supply contracts and enforcing such contractual agreements in their global value chains. By taking an extended social responsibility view in their own operations and those of their business partners, multinationals can invest in training and require local value chain 
partners to ensure decent work conditions across their entire supply chain. These investments have large positive externalities on work conditions as suppliers and distributors improve their own standards and help spread improved work practices to their own suppliers. Furthermore, multinational internal investments to increase wealth can also be attained by focusing on the poorest segments of society, the base of the pyramid (London \& Hart, 2004; Prahalad, 2005), and innovating improved and more affordable products by, for example, customizing them to the local needs (Prahalad \& Hammond, 2002). These investments can have positive externalities by providing better quality products and services (e.g., smartphones and the internet) to poor communities who can use these to upgrade their work abilities and skills, such as financial literacy and savings (Chibba, 2009).

Regarding gender equality, i.e., the equal treatment of women and men in the workplace (Eden \& Gupta, 2017), multinationals also have an opportunity to empower women within their host-country subsidiaries. Gender inequality is a "wicked problem," as it is systemic, ambiguous, complex, and conflictual, and it needs public-private partnerships to be addressed successfully (Eden \& Wagstaff, 2021). Multinationals can ensure equal benefits by actively promoting their female employees to leadership positions in subsidiaries, even when equality might not be the norm in the host country, helping them access a qualified and underutilized workforce that supports their success (Siegel, Pyun, \& Cheon, 2019). Increased gender equality can improve organizational performance (Hoogendoorn, Oosterbeek, \& van Praag 2013; Roh \& Kim, 2016) and overall global growth (Woetzel, Madgavkar, Ellingrud, Labaye, Devillard, Kutcher, Manyika, Dobbs, \& Krishnan, 2015). It also has large externalities in the local communities, as women's empowerment, combined with genderequality policies, contributes to economic development (Duflo, 2012). All these internal wealth investments benefit the firm through positive externalities by growing the market while increasing local stakeholders' purchasing power, especially individual consumers in emerging countries, contributing to SDGs 1,5 , and 8.

In line with these arguments, we propose:

Proposition 3a: Multinational wealth investments in a host-country subsidiary (e.g., sponsoring equal opportunity programs, using decent work conditions among value chain partners in the host countries) have a positive impact on the subsidiary's competitiveness (increasing the purchasing power of the local consumer base).

Proposition 3b: Multinational wealth investments in a host-country subsidiary (e.g., sponsoring equal opportunity programs, using decent work conditions among value chain partners in the host countries) generate positive wealth externalities that contribute to the host-country SDG agenda [reducing poverty (SDG 1), fostering gender equality (SDG 5), and promoting decent work and sustainable economic growth (SDG 8)].

Engaging in external investments to increase wealth in host-country communities is likely to advance the SDG agenda and generate positive externalities for multinationals at the same time. To address economic inequalities in local communities, multinationals can consider partnering with other organizations, such as local governments, non-profits, and international non-governmental organizations (VanSandt \& Sud, 2012). Such partnerships can provide a better understanding of the local communities' main deficiencies (Calton, Werhane, Hartman, \& Bevan, 2013), so that multinationals can formulate effective external investment options that have the potential to increase wealth and to foster local development. Multinationals can, for example, provide resources and training programs for their entrepreneurial efforts and support local agencies' development investments in poor communities to enable development (Eweje, 2006). To promote gender equality, multinationals can also provide training programs specifically designed for women-owned local businesses, and potentially integrate these local businesses within their value chain as local suppliers (Eden \& Wagstaff, 2021). Such investments will have a positive impact on local communities but can also generate positive externalities for the subsidiary operations, when wealthier locals are able to become entrepreneurs and potential value chain partners for the multinational and some become final consumers of the firm's products and services. They can also help attract investors who are interested in funding firms with a robust social investment ethos.

We summarize these arguments in the following propositions:

Proposition 4a: Multinational wealth investments in host-country communities (e.g., investing in entrepreneurship projects focused on 
poor consumers, implementing women's entrepreneurship programs in the host countries) have a positive impact on the host-country SDG agenda [reducing poverty (SDG 1), fostering gender equality (SDG 5), and promoting decent work and sustainable economic growth (SDG 8)].

Proposition 4b: Multinational wealth investments in host-country communities (e.g., investing in entrepreneurship projects focused on poor consumers, implementing women's entrepreneurship programs in the host countries) create positive wealth externalities for the subsidiary (securing future competitive local value chain partners and wealthier consumers).

An example of multinational devoting resources to increase wealth is Careem, an Emirati-based ridehailing service provider. Since being established in 2012, the company has expanded into 15 Middle Eastern, Northern African, and South Asian countries; in 2019, it was acquired by the US competitor Uber. Careem's core mission is "to simplify and improve the lives of people and build an awesome organization that inspires" (Careem, 2012), particularly focused on developing countries' quality of living, and its internal strategy is designed in light of the SDGs and the United Nations Women Empowerment principles. Sanam Ahmed, Director of People Engagement at Careem's subsidiary in Pakistan, indicated in an October 1, 2020 interview that "the beauty of Careem is that our entire purpose and values were already automatically aligned with the SDGs."

Since its creation, Careem has engaged in internal investments through its human resource practices that promote diversity, flexible working hours, and extended parental leaves, thereby expanding local community job opportunities in their host countries. For example, Careem employs female drivers in countries in which there is a large gender opportunity gap, including Pakistan, Egypt, and Jordan. In 2018, upon women gaining the legal ability to drive in Saudi Arabia, Careem immediately hired female drivers, attracting thousands of applicants. By empowering women and providing them with job opportunities, Careem helps the families of their female employees and stimulates structural change towards more gender-egalitarian societies, addressing SDG 5 and SDG 1 . As 70\% of Careem's riders are women, the introduction of female drivers demonstrated their commitment to customer satisfaction. By providing more secure mobility options in host countries for female clients, Careem furthers their brand loyalty and awareness and widens their client base. Careem's job opportunities for women also contribute to SDG 8 on decent work by investing, for example, in work-life benefits for their drivers while providing them with career development and education opportunities.

Careem also invests externally to increase local wealth. In the UAE, Careem partnered with the United Nations High Commissioner for Refugees (UNHCR) to offer clients the opportunity to add AED3, equivalent to USD0.82, to their trip fare. Over USD350,000 has been raised to support over 300 refugee families through the UNHCR's cash assistance program (Rung \& Fomichenko, 2019), thus contributing directly to SDG 1 on poverty. These external investments contribute to local SDG advancement and have positive externalities for Careem's ability to engage with their clients further and build its reputation as a sustainable firm that attracts repeat business.

\section{Multinationals' investments to increase health}

Both global and local health issues are central to multinationals' activities because multinationals often address health problems (Ahen, 2019). Multinational investments in host countries can contribute to not only shaping healthier lifestyles but also to creating living environments that help their stakeholders remain healthy (Salcito, Singer, Weiss, Winkler, Krieger, Wielga, \& Utzinger, 2014). These investments advance two health-related SDGs. First, SDG 2 "Zero hunger: End hunger, achieve food security and improved nutrition, and promote sustainable agriculture." There are still 690 million people, or $8.9 \%$ of the world population, who lack consistent access to food, up by 60 million in 5 years (United Nations, 2020a). Second, SDG 3 "Good health and well-being: Ensure healthy lives and promote well-being for all at all ages." A 31-year gap exists between the countries with the shortest and longest life expectancies, and at least 400 million people remain without healthcare protection (United Nations Development Programme, 2020c).

Internal investments by multinationals in hostcountry subsidiaries can provide major health-related contributions for their operations as well as for local communities. Multinationals can provide healthcare benefits and wellness programs to their employees (van Tulder, van Wijk, \& Kolk, 2009), and extend the same benefits to employees' families, especially their children, in host countries where a 
basic public healthcare system is deficient or nonexistent. Such investments can help multinationals maintain a healthier and more committed workforce as well as retain and attract better employees (Maurer, 2014). This is not only important in emerging countries but also in advanced economies where part-time employees are rarely offered health insurance (Hartman, Rubin, \& Dhanda, 2007). Moreover, multinationals can run training programs for procurement teams, suppliers, and other employees to strengthen knowledge and best practice in health and safety. For instance, multinationals can develop programs to assess the use of hazardous materials and to substitute such materials with safer alternatives within supply chains to ensure worker safety and engagement across their global value chains (Rondinelli \& Berry, 2000a, b). Investments in occupational health and safety can help multinationals to not only better manage corporate image and reputational risk but also to increase supplier productivity, while creating positive externalities in the improvement of health in local communities where these suppliers operate. Companies can also collaborate with their upstream value chain suppliers, e.g., local farmers, by transferring best sustainable farm practices so that their operations increase yield and market appeal (Gold, Hahn, \& Seuring, 2013), helping them to provide better produce to the multinational and improve the capacities of the local communities.

Lastly, multinationals can also improve health by customizing their products and services to serve their local consumers better. For instance, they can help combat hunger and malnutrition by making their products more affordable, while enriching their products with macro- and micronutrients, especially in regions where the population lacks such nutrients (Alexander, Yach, \& Mensah, 2011; Yach, 2008). Such investments in products benefit multinationals from increased sales and profits in those regions where they provide affordable and healthy products and have large positive externalities in the health of the population. Thus, internal investments by the host-country subsidiary to improve its ability to compete also help achieve SDGs 2 and 3 in host-country communities.

Based on these arguments, we present the following propositions:

Proposition 5a: Multinational health investments in a host-country subsidiary (e.g., providing healthcare benefits to their local value chain partners, designing more nutritional and affordable products for local consumers) have a positive impact on the subsidiary's competitiveness (healthier workforce and consumer base).

Proposition 5b: Multinational health investments in a host-country subsidiary (e.g., providing healthcare benefits to their local value chain partners, designing more nutritional and affordable products for local consumers) create positive health externalities that contribute to the hostcountry's SDG agenda [reducing hunger (SDG 2) and improving local health (SDG 3)].

As part of external investment, multinationals can collaborate with local governments to address healthcare infrastructure deficiencies. They can invest in building hospitals and offering training programs to healthcare workers (Outreville, 2007). These investments enable host-country subsidiaries to build strong relationships with local government authorities and civil society in host countries and to reduce the potential discrimination that can create a liability of foreignness (Zaheer, 1995). Multinationals' foreign direct investments can support local farmers' access to land, which ensures access to food and increases food security in the host countries (Santangelo, 2018). Such investments may help multinationals gain market access for farmers in rural areas of developing countries. In a similar vein, multinationals can run food assistance programs to enhance food security in local communities struggling to secure daily meals for all their members (Yach, Feldman, Bradley, \& Khan, 2010). Multinationals can also invest in providing subsidized fertilizer, certified seed, crop protection products, farm power, and rural transportation infrastructures to improve food security in local communities (Uduji \& Okolo-Obasi, 2017). Lastly, companies may fund local non-profit or non-governmental organizations that work towards enhancing agricultural productivity and nutritious foods as part of the cross-sector collaboration. In turn, such collaboration may help host-country subsidiaries understand the nutritional conditions in their host countries and design products that better serve them, while firms can define the appropriate local strategies and establish product portfolios that will promote healthier diets while they increase sales and consumer awareness (Pant \& Ramachandran, 2017).

Our arguments are encapsulated in the following propositions:

Proposition 6a: Multinational health investments in host-country communities (e.g., 
building local hospitals and medical centers and providing food assistance and healthcare education programs to local people) have a positive impact on the host-country SDG agenda [improved community health by reducing hunger (SDG 2) and local health (SDG 3)].

Proposition 6b: Multinational health investments in host-country communities (e.g., building local hospitals and medical centers and providing food assistance and healthcare education programs to local people) create positive health externalities for the host-country subsidiary (securing future access to a healthier workforce and consumer base).

Unilever, the British-Dutch consumer goods multinational, shows how a multinational not only contributes to improving health in host-country communities but also benefits from making investments consistent with the SDG agenda. For Unilever, "the SDGs are a once-in-a-lifetime opportunity to create a better world" (Unilever, 2015). Based on its global scale and reach, Unilever invests internally in a global employee health program, Lamplighter, to improve the nutrition, fitness, and mental resilience of its employees. The program includes health risk appraisals alongside exercise, nutrition, and mental resilience to help employees improve their health and well-being. In 2019, there were 81,000 Unilever employees in 75 countries, including China and India, who were enrolled in the program, which has helped improve employees' health while enhancing productivity and reducing healthcare costs. Moreover, Unilever invested $€ 85$ million to launch the Unilever Foods Innovation Center at Wageningen University in the Netherlands. The Center works on developing more plant-based ingredients and meat alternatives, nutritious foods, and sustainable food packaging, which has paved the road to improved sustainable food production systems and resilient agricultural practices (SDG 2) and reduced illness from non-communicable diseases (SDG 3). In the remarks of Unilever's former CEO, Paul Polman, during his talk at New York University on October 8, 2020, "burnt-out people are not going to fix a burntout planet."

Unilever also undertakes external health investments in local communities. It runs several health programs for handwashing, safe drinking water, sanitation, oral health, self-esteem, and skin-healing to ensure a lasting change in the hygiene of people across the globe (Unilever, 2020). For example, Lifebuoy, Unilever's hygiene soap brand, has implemented one of the world's most extensive handwashing programs, and has designed and piloted mobile technology that has been found to change handwashing behavior. The campaign increased the frequency of handwashing with soap by $50 \%$ among participants exposed to the campaign. Another Lifebuoy program is Mobile Doctarni, which is aimed at reaching women in rural areas in India, providing mothers with free, easily accessible advice about their child's health. In 2019, Unilever announced a partnership between Lifebuoy and a non-governmental organization, The Power of Nutrition, to reach 2.7 million mothers in India through Mobile Doctarni. As part of the partnership, Unilever is targeted to create a model of Mobile Doctarni that can be replicated in other locations. The Lifebuoy program addresses diseases linked to sanitation and water, which is key to contributing to the host-country SDG agenda by improving health in the local communities as well as among Unilever's employee and consumer base.

\section{Multinationals' Investments that Address the SDGs to Reduce Negative Externalities}

We also propose that multinationals can design investments that reduce the negative externalities created from their activities and contribute to achieving the SDGs. Multinationals, like any other company, have the potential to generate negative externalities in host countries where they operate as a result of their normal production and distribution activities (Meyer, 2004). We are not referring to the competitive effects of crowding out local competitors as a result of the higher competitiveness of the subsidiaries (Spencer, 2008), but to the pollution and waste generated from manufacturing, or the environmental degradation for companies in natural resources. The usual way to address these negative externalities is for the government to establish regulations that prohibit certain activities, such as dumping toxic waste, increase the cost of the negative externalities by requiring cleanup, force companies to compensate those harmed, or redesign property rights to align incentives (Arrow, 1969; Coase, 1960; Laffont, 1993). Such management of negative externalities through regulation has limitations because, in many countries, governments do not have the appropriate rules in place or are ineffective in the implementation of regulations and the prosecution of misbehavior (Geddes, 1994; Khanna \& Palepu, 2010; Migdal, 1988).

Multinationals may want to reduce negative externalities voluntarily. They can adopt non-state 
market-driven standards to reduce the regulatory sanctions that are imposed for harming local communities (Cashore, 2002; Christmann \& Taylor, 2002; King \& Lenox, 2000). This also allows the company to avoid breaking the social contract with local communities and to prevent eliciting negative reactions to their operations and future expansions. Negative externalities can lead firms to collaborate with others to establish self-regulation and to reduce external pressures (Barnett \& King, 2008). This view of addressing negative externalities to prevent harm to the multinationals' operations and reputation is the traditional approach that should be rethought.

An alternative to this traditional approach is a more proactive one in which the multinational aims to build its competitive advantage based on its ability to curtail negative externalities. By implementing superior standards in comparison to domestic competitors in the avoidance of negative externalities (King \& Shaver, 2001), the multinational can be perceived as a better company by host governments and citizens, facilitating its innovativeness and the sale of its products (Husted \& Allen, 2007). Preventing negative externalities can also be a way for the company to attract better employees, especially educated, younger ones who seem to be more concerned about the impact of companies on society (Collier \& Esteban, 2007). This second proactive approach to the management of negative externalities is the one that we follow in this article. We argue for the integration of the SDGs within segments of the value chain in which multinationals tend to have a negative impact. In this way, they can reconsider how their investments may reduce negative externalities on local communities. By incorporating the impact of negative externalities into their decision-making, multinationals can benefit from the avoidance of costly fines in the future and by differentiating themselves from competitors by embracing superior standards.

Consequently, we propose SDG groupings linked to reducing negative externalities into three main themes: the overuse of natural resources, harm to social cohesion, and overconsumption. We now examine each of the themes and their relationship to the SDGs in turn. Figure 1 illustrates these groups.

\section{Multinationals' investments to reduce the overuse of natural resources}

The overuse of natural resources at an unchecked rate has led to direct negative externalities related to the depletion and degradation of renewable and non-renewable resources, such as water, fertile soils, and forests. Natural resource exploitation generates a vast resource deficit, such that at least 1.5 Earths would be needed to regenerate the natural resources that humans use (World Wide Fund for Nature, 2014). The overuse of natural resources has also resulted in indirect negative externalities, like water, air, and soil pollution, and climate change caused by the increasing concentrations of greenhouse gases in the atmosphere. Resource extraction and processing contribute to half of all greenhouse gas emissions worldwide and about $90 \%$ of biodiversity loss (United Nations Environment Programme, 2019). As a result of human activity, global temperature has increased by 2.0 degrees Fahrenheit since 1880, and sea levels have risen by eight inches in the last century (NASA, 2020).

Multinationals can be part of the solution by incorporating their impact on natural resources into their decision-making processes. We propose that multinational efforts at reducing the overuse of natural resources can foster positive change to achieve four interconnected SDGs: SDG 6 "Clean water and sanitation: Ensure availability and sustainable management of water and sanitation for all;" SGD 7 "Affordable and clean energy: Ensure access to affordable, reliable, sustainable and modern energy for all;" SDG 13 "Climate action: Take urgent action to combat climate change and its impacts;" and SDG 15 "Life on land: Protect, restore and promote sustainable use of terrestrial ecosystems, sustainably manage forests, combat desertification, and halt and reverse land degradation and halt biodiversity loss."

Multinationals can direct their host-country subsidiaries to mitigate the excessive use of natural resources. Host-country subsidiaries can consider upgrading operations, technology, and processes across their subsidiary operational sites to reduce the amount of virgin natural resources required to manufacture products (Hills \& Welford, 2005; Marcon, de Medeiros, \& Ribeiro, 2017). Multinationals can also assist subsidiaries and suppliers in 
host countries with improving energy efficiency and increasing renewable energy use to reduce their greenhouse gas emissions at operational sites (Eskeland \& Harrison, 2003; Kolk \& Pinkse, 2008). Multinationals can invest in enhancing resource management practices by identifying subsidiary and supplier operational sites exposed to risks associated with natural resource shortages and climaterelated hazards and by assessing their resource management strategies in the context of local communities (D'Amato, Wan, Li, Rekola, \& Toppinen, 2018). These internal investments can benefit multinationals by reducing operational costs and environmental regulatory compliance costs in host countries while reducing their overall environmental footprint. In turn, such internal investments can reduce negative externalities associated with the overuse of natural resources in host communities, helping them to improve their use while preserving natural resources so that they can be used in a sustainable manner that contributes to the present and future economic development of their host communities (Hilborn, Walters, \& Ludwig, 1995). In this way, the internal investments can help the hostcountry subsidiary and concurrently contribute to the solution of the SDGs, including water withdrawal (SDG 6), fossil fuel usage (SDG 7), greenhouse gas emissions and climate-related natural disasters (SDG 13), and harm to land, forests, and territorial ecosystems (SDG 15).

These ideas support the following propositions:

Proposition 7a: Multinational investments to reduce the overuse of natural resources in a hostcountry subsidiary (e.g., reducing the use of virgin natural resources, transitioning toward renewable energy usage) have a positive impact on the subsidiary's competitiveness (reducing operational and environmental regulatory compliance costs).

Proposition 7b: Multinational investments to reduce the overuse of natural resources in a hostcountry subsidiary (e.g., reducing the use of virgin natural resources, transitioning toward renewable energy usage) mitigate negative externalities from the overuse of natural resources that contribute to the host-country SDG agenda [reducing water withdrawal (SDG 6), reducing fossil fuel usage (SDG 7), reducing greenhouse gas emissions and climate-related natural disasters (SDG 13), and reducing harm to land, forests, and territorial ecosystems (SDG 15)].
Multinational external investments also have the potential to tackle the negative externalities generated by the excessive use of natural resources in host-country communities and indirectly help the competitiveness of host-country subsidiaries. Multinationals can invest in infrastructure in underserved host countries to enhance water or energy access (Akter, Fu, Bremermann, Rosa, Nattrodt, Väätänen, Teplov, \& Khairullina, 2017), to restore polluted soil or waters for local community members, and to offer training programs to local entrepreneurs devoted to supplying renewable energy in the host-country communities. They can partner with local communities to ensure that investments in water infrastructure are successful by building local capacity to manage infrastructure (Nwankwo, Phillips, \& Tracey, 2007). These external investments can mitigate unequal access to clean water (SDG 6) and energy (SDG 7), greenhouse gas emissions (SDG 13), and degraded land and soil (SDG 15). Sequentially, these external investments can also benefit subsidiaries by ensuring future natural resource availability and quality to avoid disruption to their manufacturing and distribution networks in the host country (Bass \& Chakrabarty, 2014). Also, partnerships with local communities can serve as knowledge platforms for local sustainability issues related to the overuse of natural resources, especially where these are essential for their upstream value chain operations (Boiral \& Heras-Saizarbitoria, 2017).

The following propositions summarize these ideas:

Proposition 8a: Multinational investments to reduce the overuse of natural resources in hostcountry communities (e.g., building infrastructure to improve water and energy access, offering renewable energy training programs to local entrepreneurs) have a positive impact on the host-country SDG agenda [mitigating unequal access to clean water (SDG 6), mitigating unequal access to energy (SDG 7), mitigating greenhouse gas emissions (SDG 13), and mitigating degraded land and soil (SDG 15)].

Proposition 8b: Multinational investments to reduce the overuse of natural resources in hostcountry communities (e.g., building infrastructure to improve water and energy access, offering renewable energy training programs to local entrepreneurs) reduce negative externalities for the host-country subsidiary (securing future 
access to natural resources, avoiding disruption in their local manufacturing and distribution networks).

Schneider Electric, a French multinational providing energy and digital automation solutions with operations in over 100 countries, illustrates how multinationals can reinvent themselves to reduce negative externalities in the overuse of natural resources and contribute to host-country SDG agendas. Established in 1836 with iron, steel, and armament operations, it divested from steel and focused on electricity in the 1980s and 1990s. By 2010, the company refocused on smart grid applications to become a pioneer in digitalization and renewables to increase efficiency and sustainability in businesses, buildings, and cities. Nicolas Plain, SDG Transformation Leader at Schneider Electric, emphasized, on September 4, 2020, that "the SDGs are extremely important for all our core operations because they help us not to forget any potential side effects that our projects create in society."

Schneider Electric has made vast internal investments in developing technologies and solutions supporting the more efficient and sustainable use of natural resources in their operations. By 2020, 80\% of their energy needs were satisfied with renewables at all their sites, and they expect to be a $100 \%$ renewable energy company and achieve a net-zero carbon impact in all subsidiary operations by 2030 . To achieve this, the company has invested in photovoltaic roofs and solar microgrids across their worldwide sites (e.g., India, Thailand, France, and the US) and assisted subsidiaries in purchasing renewable energy, as in the case of the 2019 Power Purchasing Agreement signed for their facilities in Mexico (Schneider Electric, 2020a). For example, the photovoltaic roof installed in 2017 on its manufacturing facility in Gujarat, India, covers more than $50 \%$ of its energy needs, thereby reducing energy costs by $20-25 \%$ and greenhouse emissions by 1,018 tons of $\mathrm{CO}_{2}$ annually (the equivalent of planting 50,000 trees). Schneider has also developed applications such as EcoStruxure for more efficient use of energy, water, land, and minerals in industrial processes, which also cut operational costs and increased productivity and revenue, not only in their operations but also among their value chain partners. One example is the digital energy efficiency systems installed in their Mumbai Smart Distribution Center, which is expected to save $10-12 \%$ in energy and to enhance logistics efficiency by 5\% (Schneider Electric, 2020b).
Regarding external investments in host-country communities, since 2012, Schneider Electric has installed Villaya solar water pumps to supply drinking water to off-grid communities in India and several African countries (Schneider Electric, 2020c). The company has developed the Schneider Electric Energy Access program to target 350 million people without energy access in India, Bangladesh, Myanmar, Indonesia, and the Philippines, and to provide new solutions for off-grid energy access for communities in Asia and Africa (Schneider Electric, 2020c). Schneider Electric has supplied Villaya Agri-Business multi-energy power stations to provide solar electricity and heat for irrigation, lighting, fish farming, and agricultural transformation, benefiting 100,000 people in African communities and 30,000 female farmers in Asian communities. As of 2019, through their Access to Energy Training \& Entrepreneurship Program, more than 400,000 underprivileged people have already benefited from the foundation's training programs in energy management and renewable energies (Schneider Electric, 2020c). Further, the company has provided technical solar energy training to female entrepreneurs in Mali, Senegal, and Niger. Lastly, Schneider Electric joined the Global Footprint Network to partner for recycling and reuse, and to promote using resources in a way that respects the Earth's ability to replenish them. Such investments have subsequently strengthened Schneider's license to operate in its host countries, while receiving global reputation awards, such as being among the World's Most Admired Companies in 2018 and 2019 (Fortune, 2020).

\section{Multinationals' investments to reduce harm to social cohesion}

Social cohesion, which is vital to the well-being of a country, refers to both the absence of social conflict and the presence of social bonds and institutions that resolve conflict as well as civil society organizations that bridge social divisions (Kawachi \& Berkman, 2000). The SDGs can help achieve social cohesion by providing a clear, alternative basis for controlling conflict and violence, the fundamental challenge of any society (North, Wallis, Webb, \& Weingast, 2012). Many developing countries control violence and conflict by limiting access to the economic and political sectors to the ruling elites (North, Wallis, \& Weingast, 2009). As a result, elites obtain rents through their control of access to a country's economic and political life in return for abstaining from the use of violence (North et al., 
2009). The SDGs provide a different vision of reducing social tension and threats to social cohesion through an open society, which reduces inequality, fosters inclusion, and works through partnerships. Hence, social cohesion, as the reduction of social conflict and the strengthening of social bonds and peaceful conflict resolution, is related to four SDGs: SDG 10 "Reducing inequality: Reduce inequality within and among countries;" SDG 11 "Sustainable cities and communities: Make cities and human settlements inclusive, safe, resilient and sustainable;" SDG 16 "Peace, justice, and strong institutions: Promote peaceful and inclusive societies for sustainable development, provide access to justice for all and build effective, accountable and inclusive institutions at all levels;" and SDG 17 "Partnerships for the goals: Strengthen the means of implementation and revitalize the global partnership for sustainable development." Reducing inequality and fostering sustainable, inclusive communities is key to alleviating social conflict, while developing just and strong institutions through partnerships helps to generate strong social bonds and to resolve conflict peacefully. According to the United Nations (2020b), corrupt practices and tax evasion due to weak institutions foster inequality, amounting to USD1.26 trillion per year in underdeveloped countries. If this money were used to help the poor, it would push the income of people with less than USD1.25 a day to above USD1.25 for at least six years (United Nations, 2020b).

Multinationals' internal investments can help reduce barriers to social cohesion by deliberately opening access to non-elites in host-country subsidiaries. For example, companies can employ wellqualified candidates, including the clients of the patronage networks of elites, ensuring that the best candidates are hired rather than showing favoritism, which may be preferred in the host country (Allès, 2012; Donaldson \& Dunfee, 1994). Multinationals can also invest in controlling corrupt practices in subsidiaries and business partners to promote the rule of law in host countries (see a review in CuervoCazurra, 2016). Such internal investments in ethical practices produce advantages for multinationals in assuring that companies hire the most qualified employees and work with the most competitive value chain partners. At the same time, these investments create positive demonstration effects for the society at large, as employees and partners learn best practices from multinationals that adhere to high ethical standards and transmit them to their host-country context (Fisher, 2004; Inkeles, 1975;
James, 1987). Hence, these investments can reduce negative externalities generated by social conflict (Gonzalez, Layrisse, \& Lozano, 2012). As a result, these internal investments help address relative income inequality (SDG 10), exclusionary development of cities and communities (SDG 11), bribery and corruption (SDG 16), and harm to implementing partnerships for effective capacity-building in host countries (SDG 17).

Thus, we formulate the following propositions:

Proposition 9a: Multinational investments to reduce harm to social cohesion in a host-country subsidiary (e.g., widening access to employment, refraining from corruption) have a positive impact on the subsidiary's competitiveness (gaining more qualified and competitive value chain partners).

Proposition 9b: Multinational investments to reduce harm to social cohesion in a host-country subsidiary (e.g., widening access to employment, refraining from corruption) mitigate negative externalities that harm social cohesion that contribute to the host-country SDG agenda [reducing inequality (SDG 10), making cities and human settlements more inclusive (SDG 11), promoting peaceful and inclusive societies (SDG 16) and strengthening partnerships for sustainability (SDG 17)].

Multinationals can also reduce harm to social cohesion by making external investments in hostcountry communities that facilitate the reduction of negative externalities while contributing to the host-country subsidiaries' competitiveness. Partnering with grassroots non-governmental organizations is more likely to help the disadvantaged and to improve social cohesion, because they are "people doing real work, not just talking" (Spires, 2012). When partnering with elite non-governmental organizations rather than grassroots ones, multinationals can unwittingly contribute to sustaining elites and their privileges, thus reducing social cohesion (Spires, 2011). Multinationals can also target training externally, beyond their employees, to socially disadvantaged groups, such as ex-guerrilla fighters and former drug traffickers, to contribute to the reinsertion of these groups into society (Gonzalez et al., 2012). Such externally focused training reduces social conflict in host countries. These external investments can reduce barriers to participation in economic activities (SDG 10), obstacles to representation and voice for the underserved population in cities and 
communities (SDG 11), conflict and violence (SDG 16), and ineffective public-private and civil society collaborations (SDG 17). External investments also generate positive externalities for the firm that benefits from a more peaceful society, which is more attractive for potential employees and business partners, spurring greater creativity and innovation (Florida, 2002, 2003). By increasing the quality of life for employees and stakeholders located in host countries, multinationals are better able to alleviate the social unrest that negatively affects their business activities in those regions.

We summarize these ideas in the following propositions:

Proposition 10a: Multinational investments to reduce harm to social cohesion in host-country communities (e.g., partnering with grassroots nongovernmental organizations, providing training to socially disadvantaged groups) have a positive impact on the host-country SDG agenda [reducing inequality (SDG 10), making cities and settlements more inclusive (SDG 11), promoting peaceful and inclusive societies (SDG 16), and strengthening partnerships for sustainable development (SDG 17)].

Proposition 10b: Multinational investments to reduce harm to social cohesion in host-country communities (e.g., partnering with grassroots non-governmental organizations, providing training to socially disadvantaged groups) reduce negative externalities for the host-country subsidiary (reducing social unrest, thus attracting potential employees and business partners to more peaceful areas).

The case of a Mexican multinational, Coca-Cola Femsa, illustrates how firms can help reduce harm to social cohesion through internal and external investments. Coca-Cola Femsa is the largest bottler and distributor of Coca-Cola products in Latin America, and a subsidiary of the US firm Coca-Cola. In its 2019 sustainability report (Femsa, 2019), the firm describes initiatives to be a more diverse and inclusive workplace by actively employing people without regard to disability, gender, sexual orientation, culture, or age. They note how this diversity and inclusion policy seeks to benefit the work environment of the entire firm, including in hostcountry locations. Such internal investments are likely to boost employee morale and productivity as well as mitigate negative externalities engendered by social conflict by reducing unequal employment opportunity (SDG 10), exclusionary cities and communities (SDG 11), discriminatory hiring practices (SDG 16), and barriers to implementing effective capacity-building in host countries (SDG 17).

In terms of external investments in host-country communities, in 2007, Coca-Cola Femsa was invited by then-president of Colombia Alvaro Uribe to participate in peace efforts by helping with the reintegration of former paramilitary soldiers into mainstream society. The company used employees, including executives, to provide training to ex-members of the guerrilla (FARC - Revolutionary Armed Forces of Colombia) as well as right-wing paramilitary groups and mentoring on starting new businesses or preparing for employment in the formal sector of the economy (Gonzalez et al., 2012). These efforts involved collaborating in a Colombian program called the Time Bank, which coordinated volunteer participation, as well as the establishment of Community Learning Centers in some of the most remote parts of Colombia, teaching computer, math, and even basic English skills. In addition to promoting peace, these projects reached excluded groups like the guerrilla fighters and reincorporated them into the formal economy, thus helping to reduce inequality and creating more inclusive communities. Together with local Colombian firms, Coca-Cola Femsa engaged in significant cross-sector collaborations with both the government through the Alta Consejería para la Reintegración (High Council for Reintegration) and relevant Colombian non-governmental organizations, such as Colombia Presente, founded in the 1990 s to promote social responsibility and tolerance. Creating a more peaceful, inclusive culture was important to Coca-Cola Femsa, which itself had been the target of attacks, explosions, road blockages, disruptions of distribution, and even the murder and kidnapping of employees. Femsa's external investments reduced negative externalities linked to social cohesion by empowering the social, economic, and political inclusion of ex-members of the guerrilla and para-military groups (SDG 10), factors creating an unstable living environment for its communities (SDG 11), barriers to a more peaceful Colombia (SDG 16), and private-local community partnerships (SDG 17). As a result, Coca-Cola Femsa reduced business uncertainty generated by social unrest in Colombian communities.

\section{Multinationals' investments to reduce overconsumption}

The world's rapid population growth, along with the emergence of more growth-oriented economies, has accelerated overall consumption. 
Growing global consumption comes at a cost, as it exacerbates grand environmental challenges such as waste and pollution (Wiedmann et al., 2020). For instance, the world generates 2.01 billion tons of municipal solid waste annually, with at least 33\% of that mismanaged, while global waste is predicted to grow to 3.40 billion tons by 2050 (Kaza, Yao, Bhada-Tata, \& Van Woerden, 2018). It is also estimated that we use one million plastic bottles per minute and five trillion single-use plastic bags every year (United Nations Environment Programme, 2018). Plastic waste discharged in rivers reaches oceans, and is estimated to be 1.1-2.4 million tons annually (Lebreton, van der Zwet, Damsteeg, Slat, Andrady, \& Reisser, 2017), creating an unprecedented human footprint in oceans, such as the Great Pacific garbage patch.

Given their global outreach to consumers, multinationals can mitigate the negative externalities generated by overconsumption across their value chains. For instance, they have the capacity to reduce post-consumer land-based waste and prevent it from entering marine ecosystems. This focus on reducing the environmental footprint does not need to be a tradeoff for competitiveness, but can be integrated into the firm's competitive advantage (Porter \& van der Linde, 1995; Rugman \& Verbeke, 1998). Multinationals' investment options can help address these two interconnected SDGs: SDG 12 "Responsible consumption and production: Ensure sustainable consumption and production," and SDG 14 "Life below water: Sustainable use of oceans, seas, and marine resources."

Investments by host-country subsidiaries to reduce excessive consumption in the downstream portion of their value chain can help them reduce costs while at the same time reducing the negative externalities of overconsumption. Subsidiaries of multinationals can invest in product repair, reuse, and recycling facilities for local clients (Agamuthu \& Victor, 2011; Kumar \& Malegeant, 2006). Companies can also invest in optimizing local distribution networks by consolidating shipments, identifying new routes, using more efficient vehicles, and shipping directly to local distribution centers or customers (Rondinelli \& Berry, 2000a, 2000b; Srai, Alinaghian, \& Kirkwood, 2013), lowering local distribution costs. Moreover, companies can secure local distributors of biodegradable and reusable packaging materials to mitigate single-use plastic in host countries, helping them to increase their environmental credentials with consumers (Prakash \& Pathak, 2017).
These investments benefit the host-country subsidiary by reducing logistics, storage, and waste disposal costs. In turn, these multinational investments can also mitigate overconsumption-related negative externalities. Their reduction in manufacturing and post-consumer waste then lowers wasteful consumption (SDG 12) and marine pollution (SDG 14) in host-country communities.

These ideas can be summed up in the following propositions:

Proposition 11a: Multinational investments to reduce overconsumption in a host-country subsidiary (e.g., establishing product repair, reuse, and recycling facilities, optimizing local distribution networks) have a positive impact on the subsidiary's competitiveness (reducing costs related to logistics, inventory storage, and waste disposal).

Proposition 11b: Multinational investments to reduce overconsumption in a host-country subsidiary (e.g., establishing product repair, reuse, and recycling facilities, optimizing local distribution networks) mitigate negative externalities generated by overconsumption that contribute to the host-country SDG agenda [reducing postconsumer waste and overconsumption (SDG 12) and marine pollution (SDG 14)].

Multinationals can also invest externally in hostcountry communities to tackle negative externalities caused by overconsumption and, at the same time, benefit from better inputs and a more committed workforce and consumer base. Subsidiaries of multinationals can provide financial and technical support for waste management infrastructure that collects, sorts, and recycles locally-generated waste in partnership with local stakeholders, including local governments, community members, and formal and informal waste collectors (Fahmi, 2005). In this respect, multinationals may invest in training local informal waste collectors to help them better understand effective waste management practices (Longondjo Etambakonga \& Roloff, 2020). Such training is vital for both host countries and multinational subsidiaries, because informal waste sectors play a significant role in facilitating the implementation of an efficient waste collection service that businesses, formal sectors, and local governments cannot fully cover in many developing countries (Asim, Batool, \& Chaudhry, 2012; Wilson, Velis, \& Cheeseman, 2006). Finally, companies can host educational activities, programs, and community events to raise recycling 
awareness in local communities. These external investments can reduce waste (SDG 12) and ocean pollution (SDG 14) in host countries. Also, given that deficient waste management causes health issues, such as infections and respiratory problems (Yang, Ma, Thompson, \& Flower, 2018), these investments may enable firms to secure a healthier workforce and consumer base in host countries.

We summarize these arguments in the following propositions:

Proposition 12a: Multinational investments to reduce overconsumption in host-country communities (e.g., establishing a local waste management facility, training local waste collectors) have a positive impact on the host-country SDG agenda [reducing waste (SDG 12) and harm to the conservation and sustainable use of oceans and marine resources (SDG 14)].

Proposition 12b: Multinational investments to reduce overconsumption in host-country communities (e.g., establishing a local waste management facility, training local waste collectors) reduce negative externalities for the host-country subsidiary (avoiding hazardous risks and an unhealthy local workforce and consumer base).

The US computer manufacturer Hewlett-Packard (HP) has aligned its strategy with the SDGs since 2015 in its 174 facilities in 60 countries. HP makes internal investments to reduce negative externalities caused by overconsumption in downstream activities. The multinational runs customer takeback programs in 76 countries, allowing consumers to return used hardware and ink and toner cartridges for free at approved sites in those countries. Through its global take-back programs, HP recycled 117,400 tons of hardware, 14,300 tons of LaserJet toner cartridges, and 1400 tons of ink cartridges during 2019 (HP, 2020). Moreover, HP has built a supply chain for sourcing ocean-bound plastics in Haiti since 2016. The company created a market demand for recycled bottles in the local communities by upcycling them to make new print cartridges and hardware products (Peters, 2019). Such internal investments can help HP mitigate waste disposal and shipping costs by reducing new raw material purchases, and help it anticipate more stringent environmental regulations in host countries. In turn, the company's internal investments can also mitigate local waste in the post-consumer stage (SDG 12) and ocean-bound plastic and marine debris (SDG 14).
As part of its external investments to reduce overconsumption, in the early 2010s, HP provided training and consulting for Kenyan authorities to develop a sound legal framework to ensure good hazardous electronic waste disposal practices (Fox, 2014). The multinational also joined the Project STOP initiative in January 2020, in partnership with governments and communities in Southeast Asia, to create effective waste management systems that reduce waste, including plastics and metals, from being run off to the ocean. HP provides the initiative with technical support to develop a waste management system targeted to mitigate oceanbound plastics and to enhance recycling and reuse practices in East Java, Indonesia (HP, 2020). These external investments reduce waste throughout their life cycle (SDG 12) and promote sustainable use of oceans and marine resources (SDG 14) in host-country communities.

\section{DISCUSSION AND CONCLUSIONS}

We adopt a prescriptive approach to offer a new vision of multinationals that helps integrate the United Nation's 2030 Agenda for Sustainable Development into their decisions. The translation of the SDGs into areas of the extended value chain in which they are likely to have a bigger impact, and the rethinking of activities depending on the reduction of negative externalities or the increase of positive externalities, contributes to two research streams. First, the paper is topically interesting because it helps international business research address grand challenges. Second, it is also theoretically important because it forces the rethinking of the predictions of current theorization on multinational behavior through the integration of positive and negative externalities into the calculus of optimal strategy for multinationals.

\section{Expanding International Business to Address Grand Challenges}

There have been increasing debates over how international business can regain its relevance as a field of knowledge (e.g., Bapuji \& Beamish, 2019; Buckley, 2002; Buckley \& Lessard, 2005; Buckley et al., 2017). Scholars have argued that international business research has lost its connection to practice, the real world, and other disciplines (Bapuji \& Beamish, 2019; Buckley et al., 2017; Doh, 2017; Kolk, 2016). To be more impactful and to overcome existing international business research shortcomings, the international business 
field can be expanded to identifying and contributing to the solution of "big questions" that emerge at the business-society interface (Bapuji \& Beamish, 2019; Nippa \& Reuer, 2019; Prashantham \& Birkinshaw, 2020; Verbeke \& Fariborzi, 2019).

Buckley et al. (2017) suggest grand challenges such as climate change, poverty, or migration as future avenues to expand and to revitalize the international business field. Grand challenges transcend national borders and affect multiple geographic locations (Ferraro, Etzion, \& Gehman, 2015; George et al., 2016), which makes them a "multinational phenomenon by nature" (Buckley et al., 2017: 1052). Focusing on grand challenges helps reconnect international business with pressing global issues and spur research motivated by societal needs rather than theoretically-driven research gaps.

The focus on grand challenges also expands the field, since they influence the formulation and implementation of multinationals' cross-border strategies and activities as well as how value chains are managed globally (Wettstein, Giuliani, Santangelo, \& Stahl, 2019). Given the worldwide scope of multinationals, which operate in global value chains across multiple countries (Kolk \& van Tulder, 2006; Mudambi, Li, Ma, Makino, Qian, \& Boschma, 2018), and their powerful influence on multiple countries (Oetzel \& Doh, 2009; Wettstein et al., 2019), multinationals have taken the spotlight as major players in the race to tackle grand challenges and to reduce negative externalities (Buckley et al., 2017; Oetzel \& Doh, 2009; Prashantham \& Birkinshaw, 2020; van Zanten \& van Tulder, 2018; Wettstein et al., 2019).

International business research is well placed to make sense of these urgent global issues and to contribute to the efforts in other fields to find solutions for these grand challenges by guiding multinationals in the implementation of the SDGs. International business scholars can play a pivotal role in conducting rigorous academic research that can help meet the 2030 Agenda for Sustainable Development, which is critical for tackling these grand challenges while guaranteeing long-term human survival on our planet.

This article offers a research plan to connect international business research to the grand challenges of our times. The translation of the countrylevel SDGs into firm-level activities can guide managers of multinationals on how to contribute to the SDGs, and can help researchers refine their studies to address these grand challenges. We provide both the frameworks and explanations underpinning the mechanisms that explain the propositions connecting investments by multinationals to the achievement of the SDGs. We outline two mechanisms: internal investments by hostcountry subsidiaries that help them improve their competitiveness, while at the same time generating positive externalities or reducing negative externalities in the host-country community; and external investments in host-country communities directed at the externalities that can have a positive impact on the host-country subsidiary. In this way, investments by multinationals contribute to the implementation of SDGs.

International business research that addresses the 2030 Agenda for Sustainable Development explicitly is in its infancy, but previous research in international business has implicitly dealt with some of the SDGs. In Table 1, we map the connections between the SDGs and previous international business research. Existing research can extend its role and make links to the SDGs explicit, providing guidance to managers of multinationals on how their actions can contribute to each of the SDGs. Gearing research attention towards such challenges and the SDGs can help us re-connect with realworld problems and the human side of international business, while addressing the grand challenges that plague humankind. While multinationals' performance and competitiveness should remain an important avenue for international business research, an emphasis on the SDGs will help explain the human, social, and environmental implications of what multinationals do, how and where they do it, and the overall impact they have.

\section{Extending the Theorization on Multinational Behavior to Incorporate Externalities}

The concept of externalities is crucial, because it not only helps explain how multinationals can assess their impact on society and implement the SDGs in their value chains but also because it facilitates new theorization. Most of the existing theorization on multinational behavior focuses on how companies can generate and capture value (see entries in Rugman, 2009, for an overview of multinationals' literature). The usual discussion tends to be about the resources and capabilities that enable the company to build its competitive advantage, and the mechanisms it can use to transfer this competitive advantage to other countries and create new sources of advantage from 
Table 1 Examples of externality and SDG research in international business.

\begin{tabular}{|c|c|c|c|c|}
\hline Externality & SDG & SDG theme & SDG targets & IB study examples \\
\hline \multicolumn{5}{|c|}{ Positive externality } \\
\hline \multirow[t]{2}{*}{$\begin{array}{l}\text { Increasing } \\
\text { knowledge }\end{array}$} & 4 & Education & $\begin{array}{l}\text { Target } 4.3 \text {. Ensure equal access to } \\
\text { affordable education }\end{array}$ & Eweje (2006) \\
\hline & 9 & Innovation & $\begin{array}{l}\text { Target } 9.5 \text {. Enhance scientific research, } \\
\text { upgrade the technological capabilities of } \\
\text { industrial sectors in developing countries } \\
\text { by } 2030\end{array}$ & $\begin{array}{l}\text { Alcácer and Chung (2007), Almeida and } \\
\text { Phene (2004), Inkpen, Minbaeva, and } \\
\text { Tsang (2019), Jin, García, and Salomon } \\
\text { (2019), Lorenzen, Mudambi, and Schotter } \\
\text { (2020), Spencer (2008) }\end{array}$ \\
\hline \multirow[t]{5}{*}{$\begin{array}{l}\text { Increasing } \\
\text { wealth }\end{array}$} & 1 & Poverty & $\begin{array}{l}\text { Target } 1.4 \text {. Ensure that the poor and the } \\
\text { vulnerable have equal rights to economic } \\
\text { resources, as well as access to basic services } \\
\text { by } 2030\end{array}$ & $\begin{array}{l}\text { Ansari, Munir, and Gregg (2012), Asakawa, } \\
\text { Cuervo-Cazurra, and Un (2019), Halme, } \\
\text { Lindeman, and Linna (2012), Kolk et al. } \\
\text { (2018), Kolk and van Tulder (2006), } \\
\text { London and Hart (2004), Maksimov, } \\
\text { Wang, and Luo (2017) }\end{array}$ \\
\hline & 5 & Gender equality & $\begin{array}{l}\text { Target 5.5. Ensure women's full and } \\
\text { effective participation and equal } \\
\text { opportunities for leadership }\end{array}$ & $\begin{array}{l}\text { Chelekis and Mudambi (2010), Eden and } \\
\text { Wagstaff (2021), Hermans, Newburry, } \\
\text { Alvarado-Vargas, Baldo, Borda, Durán- } \\
\text { Zurita, Geleilate, Guerra, Morello, Madero- } \\
\text { Gómez, and Olivas-Lujan (2017), } \\
\text { Koveshnikov, Tienari, and Piekkari (2019), } \\
\text { Terjesen, Aguilera, and Lorenz (2015), Toh } \\
\text { and Leonardelli (2012) }\end{array}$ \\
\hline & 8 & Child labor & $\begin{array}{l}\text { Target } 8.7 \text {. End child labor in all its forms } \\
\text { by } 2025\end{array}$ & $\begin{array}{l}\text { Cho, Fang, Tayur, and Xu (2019), Kolk and } \\
\text { van Tulder }(2002,2004)\end{array}$ \\
\hline & 8 & $\begin{array}{l}\text { Employment } \\
\text { discrimination }\end{array}$ & $\begin{array}{l}\text { Target 8.5. Achieve full and productive } \\
\text { employment and decent work for all } \\
\text { women and men, including for young } \\
\text { people and persons with disabilities }\end{array}$ & Wu, Lawler, and Yi (2008) \\
\hline & 8 & $\begin{array}{l}\text { Working } \\
\text { conditions }\end{array}$ & $\begin{array}{l}\text { Target } 8.8 \text {. Protect labor rights and } \\
\text { promote safe and secure working } \\
\text { environments for all workers }\end{array}$ & $\begin{array}{l}\text { Berkey (2019), Distelhorst, Hainmueller, } \\
\text { and Locke (2017), Egels-Zanden (2014), } \\
\text { Lorenzo, Esqueda, and Larson (2010), } \\
\text { Meyer (2005), Radin and Calkins (2006), } \\
\text { van Tulder et al. (2009) }\end{array}$ \\
\hline \multirow[t]{4}{*}{$\begin{array}{l}\text { Increasing } \\
\text { health }\end{array}$} & 2 & Food security & $\begin{array}{l}\text { Target 2.3. Double the agricultural } \\
\text { productivity and incomes of small-scale } \\
\text { food producers and indigenous peoples } \\
\text { through secure and equal access to land, } \\
\text { other productive resources and inputs, and } \\
\text { knowledge }\end{array}$ & Gold et al. (2013), Santangelo (2018) \\
\hline & 3 & $\begin{array}{l}\text { Communicable } \\
\text { diseases }\end{array}$ & $\begin{array}{l}\text { Target 3.3. End the epidemics of AIDS, } \\
\text { tuberculosis, malaria and neglected tropical } \\
\text { diseases and combat hepatitis, water-borne } \\
\text { diseases and other communicable diseases }\end{array}$ & $\begin{array}{l}\text { Flanagan and Whiteman (2007), Shandra } \\
\text { et al., (2011), Sidibe (2020), Van } \\
\text { Cranenburgh and Arenas (2014) }\end{array}$ \\
\hline & 3 & $\begin{array}{l}\text { Non- } \\
\text { communicable } \\
\text { diseases }\end{array}$ & $\begin{array}{l}\text { Target 3.4. Reduce premature mortality } \\
\text { from non-communicable diseases }\end{array}$ & $\begin{array}{l}\text { Gertner and Rifkin (2018), Palazzo and } \\
\text { Richter (2005), Tempels, Blok, and Verweij } \\
(2020)\end{array}$ \\
\hline & 3 & $\begin{array}{l}\text { Environmental } \\
\text { health }\end{array}$ & $\begin{array}{l}\text { Target } 3.9 \text {. Reduce the number of deaths } \\
\text { and illnesses from hazardous chemicals and } \\
\text { air, water and soil pollution and } \\
\text { contamination }\end{array}$ & Jorgenson (2009) \\
\hline
\end{tabular}


Table 1 (Continued)

\begin{tabular}{|c|c|c|c|c|}
\hline Externality & SDG & SDG theme & SDG targets & IB study examples \\
\hline \multicolumn{5}{|c|}{ Negative externality } \\
\hline \multirow{5}{*}{$\begin{array}{l}\text { Reducing the } \\
\text { overuse of } \\
\text { natural } \\
\text { resources }\end{array}$} & 6 & Water access & $\begin{array}{l}\text { Target } 6.4 \text {. Ensure sustainable withdrawals } \\
\text { and supply of freshwater to address water } \\
\text { scarcity by } 2030\end{array}$ & $\begin{array}{l}\text { Acosta, Kim, Melzer, Mendoza, and Thelen, } \\
\text { (2011), Hills and Welford (2005) }\end{array}$ \\
\hline & 7 & $\begin{array}{l}\text { Sustainable } \\
\text { energy }\end{array}$ & $\begin{array}{l}\text { Target } 7.1 \text {. Ensure access to affordable and } \\
\text { reliable services }\end{array}$ & Akter et al. (2017) \\
\hline & 13 & Climate change & $\begin{array}{l}\text { Target } 13.3 . \text { Improve human and } \\
\text { institutional capacity on climate change } \\
\text { mitigation, adaptation, impact reduction }\end{array}$ & $\begin{array}{l}\text { Huang, Kerstein, and Wang (2018), Kolk } \\
\text { and Pinkse (2008), Patnaik (2019), Pinkse } \\
\text { and Kolk (2012) }\end{array}$ \\
\hline & 15 & Biodiversity & $\begin{array}{l}\text { Target 15.5. Take action to reduce the } \\
\text { degradation of natural habitats and halt the } \\
\text { loss of biodiversity }\end{array}$ & Boiral and Heras-Saizarbitoria (2017) \\
\hline & 15 & $\begin{array}{l}\text { Natural } \\
\text { resources }\end{array}$ & $\begin{array}{l}\text { Target } 15.1 . \text { Ensure the conservation, } \\
\text { restoration and sustainable use of terrestrial } \\
\text { and inland freshwater ecosystems }\end{array}$ & Narula (2018), Shapiro et al. (2018) \\
\hline \multirow[t]{7}{*}{$\begin{array}{l}\text { Reducing } \\
\text { harm to } \\
\text { social } \\
\text { cohesion }\end{array}$} & 10 & $\begin{array}{l}\text { Marginalized } \\
\text { populations }\end{array}$ & $\begin{array}{l}\text { Target } 10.2 \text {. Promote the social, economic } \\
\text { and political inclusion of all, irrespective of } \\
\text { age, sex, disability, race, ethnicity, origin, } \\
\text { religion or economic or other status }\end{array}$ & Newburry, Gardberg, and Sanchez (2014) \\
\hline & 10 & Migration & $\begin{array}{l}\text { Target } 10.7 . \text { Facilitate orderly, safe, regular } \\
\text { and responsible migration and mobility of } \\
\text { people }\end{array}$ & $\begin{array}{l}\text { Barnard et al. (2019), Piteli, Buckley, and } \\
\text { Kafouros (2019), Reade, McKenna, and } \\
\text { Oetzel (2019), Vaaler (2011) }\end{array}$ \\
\hline & 11 & $\begin{array}{l}\text { Natural } \\
\text { disasters }\end{array}$ & $\begin{array}{l}\text { Target } 11.5 \text {. Significantly reduce the } \\
\text { number of deaths and the number of } \\
\text { people affected and substantially decrease } \\
\text { the direct economic losses caused by } \\
\text { disasters }\end{array}$ & $\begin{array}{l}\text { Ballesteros, Useem, and Wry (2017), } \\
\text { McKnight and Linnenluecke (2019), } \\
\text { Mithani (2017), Oh, Oetzel, Rivera, and } \\
\text { Lien (2020), Zhang and Luo (2013) }\end{array}$ \\
\hline & 16 & $\begin{array}{l}\text { Violence and } \\
\text { conflict }\end{array}$ & $\begin{array}{l}\text { Target } 16 . \text { A. Strengthen capacity in } \\
\text { developing countries to prevent violence } \\
\text { and combat terrorism and crime }\end{array}$ & $\begin{array}{l}\text { Branzei and Abdelnour (2010), Li and } \\
\text { Vashchilko (2010), Liu and Li (2020), Oh } \\
\text { and Oetzel (2017) }\end{array}$ \\
\hline & 16 & Corruption & $\begin{array}{l}\text { Target } 16.5 \text {. Substantially reduce } \\
\text { corruption and bribery in all their forms }\end{array}$ & $\begin{array}{l}\text { Bertrand, Betschinger, and Laamanen } \\
\text { (2019), Cuervo-Cazurra } \\
(2006,2008 a, 2008 b), \text { Montiel, (2012), } \\
\text { Uhlenbruck, Rodriguez, Doh, and Eden } \\
\text { (2006) }\end{array}$ \\
\hline & 17 & Tax evasion & $\begin{array}{l}\text { Target } 17.1 . \text { Improve domestic capacity for } \\
\text { tax and other revenue collection }\end{array}$ & $\begin{array}{l}\text { Akamah, Hope, and Thomas (2018), } \\
\text { Gokalp, Lee, and Peng (2017), Jones } \\
\text { (2018) }\end{array}$ \\
\hline & 17 & Partnerships & $\begin{array}{l}\text { Target } 17.17 \text {. Promote effective public, } \\
\text { public-private and civil society partnerships }\end{array}$ & $\begin{array}{l}\text { Oetzel and Doh (2009), Prashantham and } \\
\text { Birkinshaw (2020), Ritvala, Salmi, and } \\
\text { Andersson (2014), Yakovleva and Vazquez- } \\
\text { Brust (2018) }\end{array}$ \\
\hline \multirow{4}{*}{$\begin{array}{l}\text { Reducing } \\
\text { over- } \\
\text { consumption }\end{array}$} & 12 & $\begin{array}{l}\text { Waste } \\
\text { management }\end{array}$ & $\begin{array}{l}\text { Target } 12.5 \text {. Substantially reduce waste } \\
\text { generation by } 2030\end{array}$ & King and Shaver (2001) \\
\hline & 12 & $\begin{array}{l}\text { Industrial } \\
\text { pollution }\end{array}$ & $\begin{array}{l}\text { Target } 12.6 \text {. Encourage transnational } \\
\text { companies to adopt sustainable practices }\end{array}$ & $\begin{array}{l}\text { Christmann and Taylor (2001), Li and Zhou } \\
\text { (2017), Rugman and Verbeke (1998), } \\
\text { Surroca et al. (2013) }\end{array}$ \\
\hline & 12 & $\begin{array}{l}\text { Global } \\
\text { sustainability } \\
\text { certifications }\end{array}$ & $\begin{array}{l}\text { Target } 12.6 . \text { Encourage transnational } \\
\text { companies to adopt sustainable practices }\end{array}$ & $\begin{array}{l}\text { Husted, Montiel, and Christmann (2016), } \\
\text { Maksimov et al. (2019), Montiel, Husted, } \\
\text { and Christmann (2019), Orcos, Pérez- } \\
\text { Aradros, and Blind (2018) }\end{array}$ \\
\hline & 14 & Ocean pollution & $\begin{array}{l}\text { Target 14.1. Prevent and reduce marine } \\
\text { pollution by } 2025\end{array}$ & Dauvergne (2018) \\
\hline
\end{tabular}


operating in a variety of locations, and how managers can coordinate decisions and operations towards profitability (Kano \& Verbeke, 2019; Tallman \& Yip, 2009; Teece, 2014).

One outcome of incorporating externalities into the theorization on multinationals' behavior is a rethinking of the sources of advantage in internationalization. For many multinationals, a significant source of their original ownership advantage is driven by the conditions of the home country (Cuervo-Cazurra, Luo, Ramamurti, \& Ang, 2018). Many home-country advantages are based on the endowments of the country and industry conditions (Porter, 1990), but some of these are based on the lack of internalization of negative externalities, such as for firms that rely on the ability to overexploit natural resources (Becker-Ritterspach, Simbeck, \& El Ebrashi, 2019; Symeou, Zyglidopoulos, \& Williamson, 2018) or labor (Siegel et al., 2019) in host countries. Others are based on the firm relying on the advantage of host-country partners that do not take into account negative externalities, such as relying on global value chains with suppliers that pollute or exploit employees (Clarke \& Boersma, 2017). These externalities build a new bridge between firm and location advantages, as the latter can be built via the positive externalities of firm investments, going beyond the traditional view of seeing firm advantage as being based on location advantages.

Another outcome of the integration of negative and positive externalities into the theorization on multinational behavior is a rethinking of the internationalization decision. On the one hand, the existence of negative externalities from the actions of the multinational forces the theorization to incorporate into managerial decisions the additional costs that the internationalization and investments create in local communities. As a result, many of the predictions of multinationals' internationalization decisions change. Much of the investment in host countries is driven by the ability of the multinational to take advantage of differences in factor conditions between the home and host countries (Ghemawat, 2007; Kogut, 1985). In some cases, these differences are driven by the ability of the multinational to exploit natural resources or labor in host countries that have poor quality regulations and protection of the rights of communities or employees. However, if the managers of the multinational take into account the costs of the negative externalities created by the multinational's exploitation of natural resources, pollution of natural habitat and the area, or the destruction of traditional social relationships and the abuse of employees, they may consider that the investment in the host country is not as profitable as in other countries where there are lower negative externalities. In fact, it may be that international expansion is not even feasible when the costs of the negative externalities are incorporated into the analysis.

Additionally, negative externalities may change the decision regarding the type of entry mode used by the multinational. Acquisitions tend to provide easy access to the host country, but they are also associated in most cases with the reorganization of operations, firing of employees, and closure of some facilities (Capron, Mitchell, \& Swaminathan, 2001). These not only have a negative impact on the employees directly affected but can also be devastating for communities that depend on the firm for much of their employment and economic development. Taking this negative externality into account may, for example, shift the decision on the entry mode away from acquisitions and towards greenfield investments.

On the other hand, incorporating the creation of positive externalities on local communities also leads to the rethinking of predictions regarding internationalization decisions. The level of external and internal investment in the host country can be modified when considering the generation of positive externalities (Boddewyn \& Doh, 2011). In locations underserved by the government, firms have to step in and build the infrastructure to be able to operate (Cuervo-Cazurra, 2018; Fisman \& Khanna, 2004). Creating positive externalities can lead the firm to undertake incrementally larger external infrastructure investments to multiply the impact on the local community, such as building a wider road to facilitate access to the operation and traffic in the community or extending the electric or water and wastewater network beyond the production plant and into nearby communities that lack access to infrastructure. This not only helps the community but also builds its reputation and local support. In a similar vein, incorporating the creation of positive externalities into decisions also modifies internal investments in the host country. Managers may expand the training of local employees to provide them with the minimum skills necessary for the job and upgrade their skills so that they can eventually become both more productive workers and local community leaders. 


\section{Future Research}

Future research can build on the arguments presented, test the propositions, and refine the ideas by addressing some of the limitations of the framework. Our prescriptive approach to multinationals' sustainability efforts provides a first approximation to the SDG paradigm for international business scholars. Nevertheless, we acknowledge that future multinational SDG studies will need to adopt a contingency approach to develop predictive models about the antecedents and the consequences of multinational activities on the SDGs. These predictive models will help to understand the connections between pre-existing international business theories and activities and grand challenges. Moreover, the extended value chain we use does not explicitly address circularity, whereby outputs are reincorporated as inputs in the system (Korhonen, Honkasalo, \& Seppälä, 2018). Adapting the system-wide framework of the circular economy to the situation of particular multinationals is an important future task. We anticipate some of this work by examining how multinationals can minimize the generation of waste. We also place each SDG along a particular segment of the extended value chain in which it is likely to have a higher impact. We intend to show where the main effect happens, but we also acknowledge the potential existence of secondary effects along with other value chain segments. Besides, by grouping the 17 SDGs within an externality framework of positive and negative externalities, we force each of the SDG into one of the six externalities. However, the SDGs not only have direct connections to the central theme in which we grouped them but also indirect ties to other themes. These potential variations in our framework can be addressed in future research by refining the level at which the SDGs are likely to have a primary and secondary effect along the extended value chain, and how the investments by the firm result in direct and indirect influence on the achievement of the SDGs.

We have discussed how multinationals can make investments to facilitate the achievement of all SDGs. This does not mean that multinationals have to address all of them. Some may prefer to focus on a few SDGs because they perceive them to be more aligned with their mission and vision, corporate culture, or strategy focus. Thus, future research should compare the relative impact of these SDG investments across types of firms. Studies can also identify which SDGs take precedence over the others, depending on the conditions of the multinational, the host-country subsidiary, and the hostcountry communities. Finally, another important research line is likely to revolve around the potential of multinationals to "SDG-wash," i.e., using the SDGs as a cover-up or as an excuse to avoid real commitment and engaging in symbolic investments with little social value (van Zanten \& van Tulder, 2018).

\section{Concluding Thoughts}

Embracing the SDG framework in international business has several advantages for both multinationals and the international business research community. As the SDGs become a common, universal framework for sustainability not only across other research disciplines like political science, sociology, and natural sciences but also among practitioners and other stakeholders including governments and non-governmental organizations (Sachs et al., 2019), our proposed SDG research agenda can have more impact and attract audiences outside the community of business academics. Moreover, SDG-centered business scholarship is likely to bring us closer to the systems approach based on coordination and collaboration needed to tackle grand challenges, as the SDGs provide a set of macro-targets to be achieved jointly and globally in close collaboration with governments and the civil society, both in the multinationals' home and host countries. Rather than business-specific and firm-level sustainability measures, such as environmental, social, and governance (ESG) metrics, SDG macro-targets work beyond the boundaries of the business sector, helping to contribute to the solution of grand challenges. The framework and explanation presented here is a guide for international business researchers to contribute to the conversation, and a call to spark action toward creating a better world.

\section{ACKNOWLEDGEMENTS}

We thank Remy Balarezo, Elisa Giuliani, Maria Alejandra Gonzalez-Perez, Robert Grosse, Leopoldo Gutierrez, Rebecca N. Mitchell, Natalia Ortiz-de-Mandojana, Andres Velez-Calle, Editor-in-Chief Alain Verbeke and three anonymous reviewers for useful suggestions for improvement of previous versions of the manuscript, and the managers of the multinationals mentioned for sharing their experience. For financial support, Cuervo-Cazurra thanks the Lloyd Mullin Fellowship, 
Montiel thanks the Lawrence N. Field Center for Entrepreneurship at Baruch College, City University of New York, and Antolín-López thanks the Spanish
Ministry of Economy, Industry and Competitiveness and the Regional Development Fund.

\section{REFERENCES}

Acosta, P., Kim, N., Melzer, I., Mendoza, R. U., \& Thelen, N. 2011. Business and human development in the base of the pyramid: Exploring challenges and opportunities with market heat maps. Journal of World Business, 46(1): 50-60.

Agamuthu, P., \& Victor, D. 2011. Policy trends of extended producer responsibility in Malaysia. Waste Management \& Research, 29(9): 945-953.

Ahen, F. 2019. Global health and international business: New frontiers of international business research. Critical Perspectives on International Business, 15(2/3): 158-178.

Akamah, H., Hope, O.-K., \& Thomas, W. B. 2018. Tax havens and disclosure aggregation. Journal of International Business Studies, 49(1): 49-69.

Akter, S., Fu, X., Bremermann, L., Rosa, M., Nattrodt, V., Väätänen, J., Teplov, R., \& Khairullina, I. 2017. MNEs' contribution to sustainable energy and development: The case of "Light for All" program in Brazil. Multinational Enterprises and Sustainable Development (International Business and Management, Vol. 33): 195-224. Emerald Publishing Limited.

Alcácer, J., \& Chung, W. 2007. Location strategies and knowledge spillovers. Management Science, 53(5): 760-776.

Alexander, E., Yach, D., \& Mensah, G. A. 2011. Major multinational food and beverage companies and informal sector contributions to global food consumption: Implications for nutrition policy. Globalization and Health, 7(1): 26.

Allès, C. 2012. The private sector and local elites: The experience of public-private partnership in the water sector in Tripoli, Lebanon. Mediterranean Politics, 17(3): 394-409.

Almeida, P., \& Phene, A. 2004. Subsidiaries and knowledge creation: The influence of the MNC and host country on innovation. Strategic Management Journal, 25(8-9): 847-864.

Ansari, S., Munir, K., \& Gregg, T. 2012. Impact at the 'bottom of the pyramid': The role of social capital in capability development and community empowerment. Journal of Management Studies, 49(4): 813-842.

Arrow, K. J. 1969. The organization of economic activity: Issues pertinent to the choice of market versus non-market allocation. In The Analysis and Evaluation of Public Expenditures: The PPB System: 47-64. US Government Printing Office.

Asakawa, K., Cuervo-Cazurra, A., \& Un, A. 2019. Frugality-based advantage. Long Range Planning, 52(4): 101809.

Asim, M., Batool, S. A., \& Chaudhry, M. N. 2012. Scavengers and their role in the recycling of waste in Southwestern Lahore. Resources, Conservation and Recycling, 58: 152-162.

Atasu, A., \& Subramanian, R. 2012. Extended producer responsibility for e-waste: Individual or collective producer responsibility? Production and Operations Management, 21(6): 1042-1059.

Aydinliyim, L. E. 2020. The case for ethical non-compete agreements: Executives versus sandwich-makers. Journal of Business Ethics. https://doi.org/10.1007/s10551-020-04570w.

Ayres, R. U., \& Kneese, A. V. 1969. Production, consumption, and externalities. The American Economic Review, 59(3): 282-297.

B Lab, \& United Nations Global Compact. 2020. SDG Action Manager. https://www.unglobalcompact.org/take-action/ sdg-action-manager. Accessed 2 April 2021.

Ballesteros, L., Useem, M., \& Wry, T. 2017. Masters of disasters? An empirical analysis of how societies benefit from corporate disaster aid. Academy of Management Journal, 60(5): 1682-1708.
Bapuji, H., \& Beamish, P. W. 2019. Impacting practice through IB scholarship: Toy recalls and the product safety crisis. Journal of International Business Studies, 50(9): 1636-1643.

Barnard, H., Deeds, D., Mudambi, R., \& Vaaler, P. M. 2019. Migrants, migration policies, and international business research: Current trends and new directions. Journal of International Business Policy, 2(4): 275-288.

Barnett, M. L., \& King, A. A. 2008. Good fences make good neighbors: A longitudinal analysis of an industry self-regulatory institution. Academy of Management Journal, 51(6): 1150-1170.

Bass, A. E., \& Chakrabarty, S. 2014. Resource security: Competition for global resources, strategic intent, and governments as owners. Journal of International Business Studies, 45(8): 961-979.

Baumol, W. J. 1972. On taxation and the control of externalities. The American Economic Review, 62(3): 307-322.

BBVA. 2018. Infographics: Pledge 2025. https://www.bbva.com/ en/infographics-pledge-2025/. Accessed 13 September 2020.

BBVA. 2019a. BBVA champions quality education for all. https:// www.bbva.com/en/bbva-champions-quality-education-forall/. Accessed 13 September 2020.

BBVA. 2019b. Financial education-The key to improving the lives of two million people in 2018. https://www.bbva.com/en/ financial-education-the-key-to-improving-the-lives-of-twomillion-people-in-2018/. Accessed 13 September 2020.

BBVA. 2020. BBVA employee online training, augmented during shelter in place. https://www.bbva.com/en/bbva-employeeonline-training-augmented-during-shelter-in-place/. Accessed 13 September 2020.

Becker-Ritterspach, F., Simbeck, K., \& El Ebrashi, R. 2019. MNCs' corporate environmental responsibility in emerging and developing economies: Toward an action research approach. Critical Perspectives on International Business, 15(2/ 3): 179-200.

Belser, P., Vazquez-Alvarez, R., \& Xu, D. (2018). Global wage report 2018/19: What lies behind gender pay gaps. International Labour Organization (ILO). https://www.ilo.org/global/ publications/books/WCMS_650553/lang-en/index.htm. Accessed 13 September 2020.

Berkey, B. 2019. Sweatshops, structural injustice, and the wrong of exploitation: Why multinational corporations have positive duties to the global poor. Journal of Business Ethics. https://doi. org/10.1007/s10551-019-04299-1.

Bertrand, O., Betschinger, M., \& Laamanen, T. 2019. Effects of subnational regional corruption on growth strategies in emerging economies: Evidence from Russian domestic and international M\&A activity. Global Strategy Journal, 9(2): 303-332.

Birkinshaw, J., Hood, N., \& Jonsson, S. 1998. Building firmspecific advantages in multinational corporations: The role of subsidiary initiative. Strategic Management Journal, 19(3): 221-242.

Blomström, M., \& Kokko, A. 1998. Multinational corporations and spillovers. Journal of Economic Surveys, 12(3): 247-277.

Blomström, M., Kokko, A., \& Mucchielli, J.-L. 2003. The economics of foreign direct investment incentives. In $\mathrm{H}$. Herrmann, \& R. Lipsey (Eds.), Foreign direct investment in the real and financial sector of industrial countries: 37-60. Cham: Springer.

Boddewyn, J., \& Doh, J. 2011. Global strategy and the collaboration of MNEs, NGOs, and governments for the 
provisioning of collective goods in emerging markets. Global Strategy Journal, 1(3-4): 345-361.

Boiral, O., \& Heras-Saizarbitoria, I. 2017. Managing biodiversity through stakeholder involvement: Why, who, and for what initiatives? Journal of Business Ethics, 140(3): 403-421.

Brammer, S., Millington, A., \& Rayton, B. 2007. The contribution of corporate social responsibility to organizational commitment. The International Journal of Human Resource Management, 18(10): 1701-1719.

Branzei, O., \& Abdelnour, S. 2010. Another day, another dollar: Enterprise resilience under terrorism in developing countries. Journal of International Business Studies, 41(5): 804-825.

Buckley, P. J. 2002. Is the international business research agenda running out of steam? Journal of International Business Studies, 33(2): 365-373.

Buckley, P. J. 2009. The impact of the global factory on economic development. Journal of World Business, 44(2): $131-143$

Buckley, P. J., Doh, J. P., \& Benischke, M. H. 2017. Towards a renaissance in international business research? Big questions, grand challenges, and the future of IB scholarship. Journal of International Business Studies, 48(9): 1045-1064.

Buckley, P. J., \& Ghauri, P. N. 2004. Globalisation, economic geography and the strategy of multinational enterprises. Journal of International Business Studies, 35(2): 81-98.

Buckley, P. J., \& Lessard, D. R. 2005. Regaining the edge for international business research. Journal of International Business Studies, 36(6): 595-599.

Burmester, B., Michailova, S., \& Stringer, C. 2019. Modern slavery and international business scholarship: The governance nexus. Critical Perspectives on International Business, 15(2/3): 139-157.

Business Roundtable. 2019. Statement on the purpose of $a$ corporation. https://opportunity.businessroundtable.org/ ourcommitment/. Accessed 13 September 2020.

Calton, J. M., Werhane, P. H., Hartman, L. P., \& Bevan, D. 2013. Building partnerships to create social and economic value at the base of the global development pyramid. Journal of Business Ethics, 117(4): 721-733.

Cantwell, J., \& Piscitello, L. 2005. Recent location of foreignowned research and development activities by large multinational corporations in the European regions: The role of spillovers and externalities. Regional Studies, 39(1): 1-16.

Capron, L., Mitchell, W., \& Swaminathan, A. 2001. Asset divestiture following horizontal acquisitions: A dynamic view. Strategic Management Journal, 22(9): 817-844.

Careem. 2012. The Careem story-Learn more about Careem's mission. https://www.careem.com/our-story/. Accessed 13 September 2020.

Cashore, B. 2002. Legitimacy and the privatization of environmental governance: How non-state market-driven (NSMD) governance systems gain rule-making authority. Governance, 15(4): 503-529.

Castellani, D., \& Zanfei, A. 2006. Multinational firms, innovation and productivity. Cheltenham: Edward Elgar.

Chelekis, J., \& Mudambi, S. M. 2010. MNCs and microentrepreneurship in emerging economies: The case of Avon in the Amazon. Journal of International Management, 16(4): 412-424.

Chibba, M. 2009. Financial inclusion, poverty reduction and the Millennium Development Goals. The European Journal of Development Research, 21(2): 213-230.

Cho, S.-H., Fang, X., Tayur, S., \& Xu, Y. 2019. Combating child labor: Incentives and information disclosure in global supply chains. Manufacturing \& Service Operations Management, 21(3): 692-711.

Christmann, P., \& Taylor, G. 2001. Globalization and the environment: Determinants of firm self-regulation in China. Journal of International Business Studies, 32(3): 439-458.

Christmann, P., \& Taylor, G. 2002. Globalization and the environment: Strategies for international voluntary environmental initiatives. Academy of Management Perspectives, 16(3): 121-135.

Clarke, T., \& Boersma, M. 2017. The governance of global value chains: Unresolved human rights, environmental and ethical dilemmas in the Apple supply chain. Journal of Business Ethics, 143(1): 111-131.

Coase, R. H. 1960. The problem of social cost. The Journal of Law and Economics, 3: 1-44.

Collier, J., \& Esteban, R. 2007. Corporate social responsibility and employee commitment. Business Ethics: A European Review, 16(1): 19-33.

Cuervo-Cazurra, A. 2006. Who cares about corruption? Journal of International Business Studies, 37(6): 807-822.

Cuervo-Cazurra, A. 2008a. The effectiveness of laws against bribery abroad. Journal of International Business Studies, 39(4): 634-651.

Cuervo-Cazurra, A. 2008b. Better the devil you don't know: Types of corruption and FDI in transition economies. Journal of International Management, 14(1): 12-27.

Cuervo-Cazurra, A. 2016. Corruption in international business. Journal of World Business, 51(1): 35-49.

Cuervo-Cazurra, A. 2018. The evolution of business groups' corporate social responsibility. Journal of Business Ethics, 153(4): 997-1016.

Cuervo-Cazurra, A., Luo, Y., Ramamurti, R., \& Ang, S. H. 2018. The impact of the home country on internationalization. Journal of World Business, 53(5): 593-604.

D'Amato, D., Wan, M., Li, N., Rekola, M., \& Toppinen, A. 2018. Managerial views of corporate impacts and dependencies on ecosystem services: A case of international and domestic forestry companies in China. Journal of Business Ethics, 150(4): 1011-1028.

Dahan, N. M., Doh, J. P., Oetzel, J., \& Yaziji, M. 2010. Corporate-NGO collaboration: Co-creating new business models for developing markets. Long Range Planning, 43(2): 326-342.

Das, S. 1987. Externalities, and technology transfer through multinational corporations: A theoretical analysis. Journal of International Economics, 22(1): 171-182.

Dauvergne, P. 2018. Why is the global governance of plastic failing the oceans? Global Environmental Change, 51: 22-31.

de Faria, P., \& Sofka, W. 2010. Knowledge protection strategies of multinational firms-A cross-country comparison. Research Policy, 39(7): 956-968.

Distelhorst, G., Hainmueller, J., \& Locke, R. M. 2017. Does lean improve labor standards? Management and social performance in the Nike supply chain. Management Science, 63(3): 707-728.

Doh, I. 2017. Phenomenon-based research in international business: Making IB relevant again. AlB Insights, 17(2): 14-16. Donaldson, T., \& Dunfee, T. W. 1994. Toward a unified conception of business ethics: Integrative social contracts theory. Academy of Management Review, 19(2): 252-284.

Donoher, W. J. 2017. The multinational and the legitimation of sustainable development. Transnational Corporations, 24(3): 49-60.

Duflo, E. 2012. Women empowerment and economic development. Journal of Economic Literature, 50(4): 1051-1079.

Dyer, J. H. 2000. Collaborative advantage: Winning through extended enterprise supplier networks. New York: Oxford University Press.

Easterly, W. 2015. The SDGs should stand for senseless, dreamy, garbled. Foreign Policy. https://foreignpolicy.com/2015/09/ 28/the-sdgs-are-utopian-and-worthless-mdgs-developmentrise-of-the-rest/. Accessed 29 November 2019.

Eden, L., \& Gupta, S. F. 2017. Culture and context matter: Gender in international business and management. Cross Cultural \& Strategic Management, 24(2): 194-210.

Eden, L., \& Wagstaff, M. F. 2021. Evidence-based policymaking and the wicked problem of SDG 5 Gender Equality. Journal of International Business Policy, 4(1): 28-57. 
Egels-Zanden, N. 2014. Revisiting supplier compliance with MNC codes of conduct: Recoupling policy and practice at Chinese toy suppliers. Journal of Business Ethics, 119(1): 59-75.

Eskeland, G. S., \& Harrison, A. E. 2003. Moving to greener pastures? Multinationals and the pollution haven hypothesis. Journal of Development Economics, 70(1): 1-23.

Eweje, G. 2006. The role of MNEs in community development initiatives in developing countries: Corporate social responsibility at work in Nigeria and South Africa. Business \& Society, 45(2): 93-129.

Fahmi, W. S. 2005. The impact of privatization of solid waste management on the Zabaleen garbage collectors of Cairo. Environment and Urbanization, 17(2): 155-170.

Farndale, E., Scullion, H., \& Sparrow, P. 2010. The role of the corporate HR function in global talent management. Journal of World Business, 45(2): 161-168.

Femsa. 2019. Femsa sustainability contents 2019. https://www. femsa.com/assets/2020/03/FEMSA_GRI_2019En.pdf. Accessed 13 September 2020

Ferner, A., Almond, P., \& Colling, T. 2005. Institutional theory and the cross-national transfer of employment policy: The case of "workforce diversity" in US multinationals. Journal of International Business Studies, 36(3): 304-321.

Ferraro, F., Etzion, D., \& Gehman, J. 2015. Tackling grand challenges pragmatically: Robust action revisited. Organization Studies, 36(3): 363-390.

Fisher, D. 2004. The demonstration effect revisited. Annals of Tourism Research, 31(2): 428-446.

Fisman, R., \& Khanna, T. 2004. Facilitating development: The role of business groups. World Development, 32(4): 609-628.

Flanagan, W., \& Whiteman, G. 2007. "AIDS is not a business": A study in global corporate responsibility - Securing access to low-cost HIV medications. Journal of Business Ethics, 73(1): $65-75$

Florida, R. 2002. The economic geography of talent. Annals of the Association of American Geographers, 92(4): 743-755.

Florida, R. 2003. Cities and the creative class. City \& Community, 2(1): 3-19.

Fortune. 2020. World's most admired companies. https://fortune. com/worlds-most-admired-companies/2020/. Accessed 13 September 2020.

Fosfuri, A., Motta, M., \& Rønde, T. 2001. Foreign direct investment and spillovers through workers' mobility. Journal of International Economics, 53(1): 205-222.

Fox, N. 2014. Hewlett-Packard introduces large-scale e-waste recycling in Africa. The Guardian. http://www.theguardian. $\mathrm{com} /$ sustainable-business/sustainability-case-studies-hewlettpackard-ewaste-recycling-africa. Accessed 13 September 2020.

Garber, G. R. 2013. Noncompete clauses: Employee mobility, innovation ecosystems, and multinational R\&D offshoring. Berkeley Technology Law Journal, 28(Annual Review Issue): 1079-1110.

Geddes, B. 1994. Politician's dilemma: Building state capacity in Latin America. Berkeley: University of California Press.

George, G., Howard-Grenville, J., Joshi, A., \& Tihanyi, L. 2016. Understanding and tackling societal grand challenges through management research. Academy of Management Journal, 59(6): 1880-1895.

Gershenberg, I. 1987. The training and spread of managerial know-how: A comparative analysis of multinational and other firms in Kenya. World Development, 15(7): 931-939.

Gertner, D., \& Rifkin, L. 2018. Coca-Cola and the fight against the global obesity epidemic. Thunderbird International Business Review, 60(2): 161-173.

Ghemawat, P. 2007. Redefining global strategy: Crossing borders in a world where differences still matter. Cambridge, MA:Harvard Business School Press.

Giuliani, E., Santangelo, G. D., \& Wettstein, F. 2016. Human rights and international business research: A call for studying emerging market multinationals. Management \& Organization Review, 12(3): 631-637.

Global Reporting Initiative, United Nations Global Compact, \& World Business Council for Sustainable Development. 2015. SDG Compass: The guide for business action on the SDGs. https://sdgcompass.org/wp-content/uploads/2015/12/ 019104_SDG_Compass_Guide_2015.pdf. Accessed September 2020

Gokalp, O. N., Lee, S.-H., \& Peng, M. W. 2017. Competition and corporate tax evasion: An institution-based view. Journal of World Business, 52(2): 258-269.

Gold, S., Hahn, R., \& Seuring, S. 2013. Sustainable supply chain management in "Base of the Pyramid" food projects-A path to triple bottom line approaches for multinationals? International Business Review, 22(5): 784-799.

Gonzalez, R. A., Layrisse, F., \& Lozano, G. 2012. Coca-Cola FEMSA's contribution to peace. Case No. SKE143-PDF-ENG. Harvard Business School Publishing.

Griggs, D., Stafford-Smith, M., Gaffney, O., Rockström, J., Ohman, M. C., Shyamsundar, P., Steffen, W., Glaser, G., Kanie, N., \& Noble, I. 2013. Sustainable development goals for people and planet. Nature, 495(7441): 305-307.

Grinstein, A., \& Riefler, P. 2015. Citizens of the (green) world? Cosmopolitan orientation and sustainability. Journal of International Business Studies, 46(6): 694-714.

Halme, M., Lindeman, S., \& Linna, P. 2012. Innovation for inclusive business: Intrapreneurial bricolage in multinational corporations. Journal of Management Studies, 49(4): 743-784.

Hartman, L., Rubin, R., \& Dhanda, K. 2007. The communication of corporate social responsibility: United States and European Union multinational corporations. Journal of Business Ethics, 74(4): 373-389.

Hermans, M., Newburry, W., Alvarado-Vargas, M. J., Baldo, C. M., Borda, A., Durán-Zurita, E. G., Geleilate, J. M. G., Guerra, M., Morello, M. V. L., Madero-Gómez, S. M., \& Olivas-Lujan, M. R. 2017. Attitudes towards women's career advancement in Latin America: The moderating impact of perceived company international proactiveness. Journal of International Business Studies, 48(1): 90-112.

Hilborn, R., Walters, C. J., \& Ludwig, D. 1995. Sustainable exploitation of renewable resources. Annual Review of Ecology and Systematics, 26: 45-67.

Hills, J., \& Welford, R. 2005. Coca-Cola and water in India. Corporate Social Responsibility and Environmental Management, 12(3): 168-177.

Hoogendoorn, S., Oosterbeek, H., \& van Praag, M. 2013. The impact of gender diversity on the performance of business teams: Evidence from a field experiment. Management Science, 59(7): 1514-1528.

HP. 2020. HP 2019 sustainable impact report. https://h20195. www2.hp.com/v2/GetDocument.aspx?docname=c06601778. Accessed 13 September 2020.

Huang, H. H., Kerstein, J., \& Wang, C. 2018. The impact of climate risk on firm performance and financing choices: An international comparison. Journal of International Business Studies, 49(5): 633-656.

Husted, B. W. 2003. Governance choices for corporate social responsibility: To contribute, collaborate or internalize? Long Range Planning, 36(5): 481-498.

Husted, B. W., \& Allen, D. B. 2007. Strategic corporate social responsibility and value creation among large firms: Lessons from the Spanish experience. Long Range Planning, 40(6): 594-610.

Husted, B. W., Montiel, I., \& Christmann, P. 2016. Effects of local legitimacy on certification decisions to global and national CSR standards by multinational subsidiaries and domestic firms. Journal of International Business Studies, 47(3): 382-397.

Inkeles, A. 1975. Becoming modern: Individual change in six developing countries. Ethos, 3(2): 323-342. 
Inkpen, A., Minbaeva, D., \& Tsang, E. W. K. 2019. Unintentional, unavoidable, and beneficial knowledge leakage from the multinational enterprise. Journal of International Business Studies, 50(2): 250-260.

Ite, U. E. 2004. Multinationals and corporate social responsibility in developing countries: A case study of Nigeria. Corporate Social Responsibility and Environmental Management, 11(1): $1-11$.

James, J. 1987. Positional goods, conspicuous consumption and the international demonstration effect reconsidered. World Development, 15(4): 449-462.

Jiang, G. F., Jung, J. C., \& Makino, S. 2020. Parent firm corporate social responsibility and overseas subsidiary performance: A signaling perspective. Journal of World Business. https://doi. org/10.1016/j.jwb.2020.101141.

Jin, B., García, F., \& Salomon, R. 2019. Inward foreign direct investment and local firm innovation: The moderating role of technological capabilities. Journal of International Business Studies, 50(5): 847-855.

Jones, C., Temouri, Y., \& Cobham, A. 2018. Tax haven networks and the role of the Big 4 accountancy firms. Journal of World Business, 53(2): 177-193.

Jorgenson, A. K. 2009. Foreign direct investment and the environment, the mitigating influence of institutional and civil society factors, and relationships between industrial pollution and human health: A panel study of less-developed countries. Organization \& Environment, 22(2): 135-157.

Kano, L. 2018. Global value chain governance: A relational perspective. Journal of International Business Studies, 49(6): 684-705.

Kano, L., \& Verbeke, A. 2019. Theories of the multinational firm: A microfoundational perspective. Global Strategy Journal, 9(1): 117-147.

Kawachi, I., \& Berkman, L. F. 2000. Social cohesion, social capital, and health. In L. F. Berkman, \& I. Kawachi (Eds.), Social epidemiology: 174-190. New York: Oxford University Press.

Kaza, S., Yao, L. C., Bhada-Tata, P., \& Van Woerden, F. 2018. What a waste 2.0: A global snapshot of solid waste management to 2050. Washington, DC:World Bank.

Khanna, T., \& Palepu, K. G. 2010. Winning in emerging markets: $A$ road map for strategy and execution. Cambridge, MA: Harvard Business Press.

Kim, Y. H., \& Davis, G. F. 2016. Challenges for global supply chain sustainability: Evidence from conflict minerals reports. Academy of Management Journal, 59(6): 1896-1916.

King, A. A., \& Lenox, M. J. 2000. Industry self-regulation without sanctions: The chemical industry's responsible care program. Academy of Management Journal, 43(4): 698-716.

King, A. A., \& Shaver, J. M. 2001. Are aliens green? Assessing foreign establishments' environmental conduct in the United States. Strategic Management Journal, 22(11): 1069-1085.

Klöpffer, W. 1997. Life cycle assessment. Environmental Science and Pollution Research, 4(4): 223-228.

Kogut, B. 1985. Designing global strategies: Comparative and competitive value-added chains. Sloan Management Review (pre-1986), 26(4): 15-28.

Kogut, B., \& Zander, U. 1993. Knowledge of the firm and the evolutionary theory of the multinational corporation. Journal of International Business Studies, 24(4): 625-645.

Kolk, A. 2010. Trajectories of sustainability reporting by MNCs. Journal of World Business, 45(4): 367-374.

Kolk, A. 2016. The social responsibility of international business: From ethics and the environment to CSR and sustainable development. Journal of World Business, 51(1): 23-34.

Kolk, A., Kourula, A., \& Pisani, N. 2017. Multinational enterprises and the Sustainable Development Goals: What do we know and how to proceed? Transnational Corporations, 24(3): 9-32.

Kolk, A., \& Pinkse, J. 2008. A perspective on multinational enterprises and climate change: Learning from "an inconvenient truth"? Journal of International Business Studies, 39(8): 1359-1378.

Kolk, A., Rivera-Santos, M., \& Rufín, C. 2018. Multinationals, international business, and poverty: A cross-disciplinary research overview and conceptual framework. Journal of International Business Policy, 1(1-2): 92-115.

Kolk, A., \& van Tulder, R. 2002. Child labor and multinational conduct: A comparison of international business and stakeholder codes. Journal of Business Ethics, 36(3): 291-301.

Kolk, A., \& van Tulder, R. 2004. Ethics in international business: Multinational approaches to child labor. Journal of World Business, 39(1): 49.

Kolk, A., \& van Tulder, R. 2006. Poverty alleviation as business strategy? Evaluating commitments of frontrunner multinational corporations. World Development, 34(5): 789-801.

Korhonen, J., Honkasalo, A., \& Seppälä, J. 2018. Circular economy: The concept and its limitations. Ecological Economics, 143: 37-46.

Koveshnikov, A., Tienari, J., \& Piekkari, R. 2019. Gender in international business journals: A review and conceptualization of MNCs as gendered social spaces. Journal of World Business, 54(1): 37-53.

Kumar, S., \& Malegeant, P. 2006. Strategic alliance in a closedloop supply chain, a case of manufacturer and eco-non-profit organization. Technovation, 26(10): 1127-1135.

Laffont, J.-J. 1993. A theory of incentives in procurement and regulation. Cambridge, MA: MIT Press.

Lebreton, L. C. M., van der Zwet, J., Damsteeg, J.-W., Slat, B., Andrady, A., \& Reisser, J. 2017. River plastic emissions to the world's oceans. Nature Communications, 8(1): 15611.

Lev, B., Petrovits, C., \& Radhakrishnan, S. 2010. Is doing good good for you? How corporate charitable contributions enhance revenue growth. Strategic Management Journal, 31(2): 182-200.

Li, Q., \& Vashchilko, T. 2010. Dyadic military conflict, security alliances and bilateral FDI flows. Journal of International Business Studies, 41(5): 765-782.

Li, X., \& Zhou, Y. M. 2017. Offshoring pollution while offshoring production? Strategic Management Journal, 38(11): 2310-2329.

Linnenluecke, M. K., \& Griffiths, A. 2010. Corporate sustainability and organizational culture. Journal of World Business, 45(4): 357-366.

Liu, C., \& Li, D. 2020. Divestment response to host-country terrorist attacks: Inter-firm influence and the role of temporal consistency. Journal of International Business Studies, 51: 1331-1346.

London, T., \& Hart, S. L. 2004. Reinventing strategies for emerging markets: Beyond the transnational model. Journal of International Business Studies, 35(5): 350-370.

Longondjo Etambakonga, C., \& Roloff, J. 2020. Protecting environment or people? Pitfalls and merits of informal labour in the Congolese recycling industry. Journal of Business Ethics, 161(4): 815-834.

Lorenzen, M., Mudambi, R., \& Schotter, A. 2020. International connectedness and local disconnectedness: MNE strategy, city-regions and disruption. Journal of International Business Studies, 51(8): 1199-1222.

Lorenzo, O., Esqueda, P., \& Larson, J. 2010. Safety and ethics in the global workplace: Asymmetries in culture and infrastructure. Journal of Business Ethics, 92(1): 87-106.

MacFeely, S. 2019. The big (data) bang: Opportunities and challenges for compiling SDG indicators. Global Policy, 10(S1): 121-133.

Maksimov, V., Wang, S. L., \& Luo, Y. 2017. Reducing poverty in the least developed countries: The role of small and medium enterprises. Journal of World Business, 52(2): 244-257.

Maksimov, V., Wang, S. L., \& Yan, S. 2019. Global connectedness and dynamic green capabilities in MNEs. Journal of International Business Studies. https://doi.org/10.1057/ s41267-019-00275-z. 
Marcon, A., de Medeiros, J. F., \& Ribeiro, J. L. D. 2017. Innovation and environmentally sustainable economy: Identifying the best practices developed by multinationals in Brazil. Journal of Cleaner Production, 160: 83-97.

Maurer, R. 2014. Global benefits management must adapt to a changing landscape. Society for Human Resource Management (SHRM). https://www.shrm.org/resourcesandtools/hr-topics/ global-hr/pages/global-benefits-management.aspx. Accessed 13 September 2020.

McKnight, B., \& Linnenluecke, M. K. 2019. Patterns of firm responses to different types of natural disasters. Business \& Society, 58(4): 813-840.

Meyer, K. E. 2004. Perspectives on multinational enterprises in emerging economies. Journal of International Business Studies, 35(4): 259-276.

Meyer, K. E. 2005. Rising above sweatshops: Innovative approaches to global labor challenges. Journal of International Business Studies, 36(2): 246-249.

Migdal, J. S. 1988. Strong societies and weak states: State-society relations and state capabilities in the Third World. Princeton, N): Princeton University Press.

Mithani, M. 2017. Liability of foreignness, natural disasters, and corporate philanthropy. Journal of International Business Studies, 48(8): 941-963.

Montiel, I., Christmann, P., \& Zink, T. 2019. The effect of sustainability standard uncertainty on certification decisions of firms in emerging economies. Journal of Business Ethics, 154(3): 667-681

Montiel, I., Husted, B. W., \& Christmann, P. 2012. Using private management standard certification to reduce information asymmetries in corrupt environments. Strategic Management Journal, 33(9): 1103-1113.

Mudambi, R., Li, L., Ma, X., Makino, S., Qian, G., \& Boschma, R. 2018. Zoom in, zoom out: Geographic scale and multinational activity. Journal of International Business Studies, 49(8): 929-941.

Nandkumar, A., \& Srikanth, K. 2016. Right person in the right place: How the host country IPR influences the distribution of inventors in offshore $R \& D$ projects of multinational enterprises. Strategic Management Journal, 37(8): 1715-1733.

Narula, R. 2018. Multinational firms and the extractive sectors in the 21 st century: Can they drive development? Journal of World Business, 53(1): 85-91.

NASA. 2020. Climate change evidence: How do we know? https:// climate.nasa.gov/evidence. Accessed 13 September 2020.

Newburry, W., Gardberg, N. A., \& Sanchez, J. I. 2014. Employer attractiveness in Latin America: The association among foreignness, internationalization and talent recruitment. Journal of International Management, 20(3): 327-344.

Newenham-Kahindi, A. M. 2011. A global mining corporation and local communities in the Lake Victoria zone: The case of Barrick Gold multinational in Tanzania. Journal of Business Ethics, 99(2): 253-282.

Nilsson, M., Chisholm, E., Griggs, D., Howden-Chapman, P., McCollum, D., Messerli, P., Neumann, B., Stevance, A. S., Visbeck, M., \& Stafford-Smith, M. 2018. Mapping interactions between the sustainable development goals: Lessons learned and ways forward. Sustainability Science, 13(6): 1489-1503.

Nippa, M., \& Reuer, J. J. 2019. On the future of international joint venture research. Journal of International Business Studies, 50(4): 555-597.

North, D. C., Wallis, J. J., Webb, S. B., \& Weingast, B. R. 2012. Limited access orders. In B. R. Weingast, D. C. North, J. J. Wallis, \& S. B. Webb (Eds.), In the shadow of violence: Politics, economics, and the problems of development: 1-23. Cambridge: Cambridge University Press.

North, D. C., Wallis, J. J., \& Weingast, B. R. 2009. Violence and social orders: A conceptual framework for interpreting recorded human history. Cambridge: Cambridge University Press.

Nwankwo, E., Phillips, N., \& Tracey, P. 2007. Social investment through community enterprise: The case of multinational corporations involvement in the development of Nigerian water resources. Journal of Business Ethics, 73(1): 91-101.

Oetzel, J., \& Doh, J. P. 2009. MNEs and development: A review and reconceptualization. Journal of World Business, 44(2): $108-120$.

Oh, C. H., \& Oetzel, J. 2017. Once bitten twice shy? Experience managing violent conflict risk and MNC subsidiary-level investment and expansion. Strategic Management Journal, 38(3): 714-731.

Oh, C. H., Oetzel, J., Rivera, J., \& Lien, D. 2020. Natural disasters and MNC sub-national investments in China. Multinational Business Review, 28(2): 245-274.

Orcos, R., Pérez-Aradros, B., \& Blind, K. 2018. Why does the diffusion of environmental management standards differ across countries? The role of formal and informal institutions in the adoption of ISO 14001. Journal of World Business, 53(6): 850-861.

Outreville, J. F. 2007. Foreign direct investment in the health care sector and most-favoured locations in developing countries. The European lournal of Health Economics, 8(4): 305-312.

Oxfam. 2020. Why the majority of the world's poor are women. https://www.oxfam.org/en/why-majority-worlds-poor-arewomen. Accessed 13 September 2020.

Palazzo, G., \& Richter, U. 2005. CSR business as usual? The case of the tobacco industry. Journal of Business Ethics, 61(4): 387-401.

Pant, A., \& Ramachandran, J. 2017. Navigating identity duality in multinational subsidiaries: A paradox lens on identity claims at Hindustan Unilever 1959-2015. Journal of International Business Studies, 48(6): 664-692.

Patnaik, S. 2019. A cross-country study of collective political strategy: Greenhouse gas regulations in the European Union. Journal of International Business Studies, 50(7): 1130-1155.

Peng, M. W. 2004. Identifying the big question in international business research. Journal of International Business Studies, 35(2): 99-108.

Perri, A., Andersson, U., Nell, P. C., \& Santangelo, G. D. 2013. Balancing the trade-off between learning prospects and spillover risks: MNC subsidiaries' vertical linkage patterns in developed countries. Journal of World Business, 48(4): 503-514.

Peters, A. 2019. This new HP laptop is the first computer to use ocean-bound plastic. Fast Company. https://www. fastcompany.com/90405131/this-new-hp-latpop-is-the-firstcomputer-to-use-ocean-bound-plastic. Accessed 13 September 2020 .

Pinkse, J., \& Kolk, A. 2012. Multinational enterprises and climate change: Exploring institutional failures and embeddedness. Journal of International Business Studies, 43(3): 332-341.

Piteli, E. E. N., Buckley, P. J., \& Kafouros, M. 2019. Do remittances to emerging countries improve their economic development? Understanding the contingent role of culture. Journal of International Management, 25(4): 100675.

Porter, M. E. 1985. Competitive advantage: Creating and sustaining superior performance. New York: Free Press.

Porter, M. E. 1990. The competitive advantage of nations. Harvard Business Review, 68(2): 73-93.

Porter, M. E., \& van der Linde, C. 1995. Green and competitive: Ending the stalemate. Harvard Business Review, 73(5): 120-134.

Prahalad, C. K. 2005. The fortune at the bottom of the pyramid. Wharton School Pub.

Prahalad, C. K., \& Hammond, A. 2002. Serving the world's poor, profitably. Harvard Business Review, 80(9): 48-59.

Prakash, G., \& Pathak, P. 2017. Intention to buy eco-friendly packaged products among young consumers of India: A study on developing nation. Journal of Cleaner Production, 141: 385-393.

Prashantham, S., \& Birkinshaw, J. 2020. MNE-SME cooperation: An integrative framework. Journal of International Business Studies, 51(7): 1161-1175. 
Radin, T. J., \& Calkins, M. 2006. The struggle against sweatshops: Moving toward responsible global business. Journal of Business Ethics, 66(2-3): 261-272.

Reade, C., McKenna, M., \& Oetzel, J. 2019. Unmanaged migration and the role of MNEs in reducing push factors and promoting peace: A strategic HRM perspective. Journal of International Business Policy, 2(4): 377-396.

Reiche, B. S. 2008. The configuration of employee retention practices in multinational corporations' foreign subsidiaries. International Business Review, 17(6): 676-687.

Ritvala, T., Salmi, A., \& Andersson, P. 2014. MNCs and local cross-sector partnerships: The case of a smarter Baltic Sea. International Business Review, 23(5): 942-951.

Roh, H., \& Kim, E. 2016. The business case for gender diversity: Examining the role of human resource management investments. Human Resource Management, 55(3): 519-534.

Rondinelli, D. A., \& Berry, M. A. 2000. Multimodal transportation, logistics, and the environment: Managing interactions in a global economy. European Management Journal, 18(4): 398-410.

Rondinelli, D. A., \& Berry, M. A. 2000. Environmental citizenship in multinational corporations: Social responsibility and sustainable development. European Management Journal, 18(1): 70-84.

Rugman, A. M. 2009. The Oxford handbook of international business (2nd ed.). New York: Oxford University Press.

Rugman, A. M., \& Verbeke, A. 1998. Corporate strategies and environmental regulations: An organizing framework. Strategic Management Journal, 19(4): 363-375.

Rung, G., \& Fomichenko, N. 2019. Achieving Sustainable Development Goals in the UAE. Oliver Wyman. https://www. oliverwyman.com/content/dam/oliver-wyman/v2/publications/ 2019/july/achieving-the-sustainable-development-goals-in-theuae-.pdf. Accessed 13 September 2020.

Rygh, A. 2019. Social value creation by multinational enterprises: The next "Big Question" for international business research? Critical Perspectives on International Business, 16(1): 47-75.

Sachs, J. D., Schmidt-Traub, G., Mazzucato, M., Messner, D., Nakicenovic, N., \& Rockström, J. 2019. Six Transformations to achieve the Sustainable Development Goals. Nature Sustainability, 2(9): 805-814.

Salcito, K., Singer, B. H., Weiss, M. G., Winkler, M. S., Krieger, G. R., Wielga, M., \& Utzinger, J. 2014. Multinational corporations and infectious disease: Embracing human rights management techniques. Infectious Diseases of Poverty, 3(1): 39.

Salvia, A. L., Leal Filho, W., Brandli, L. L., \& Griebeler, J. S. 2019. Assessing research trends related to Sustainable Development Goals: Local and global issues. Journal of Cleaner Production, 208: 841-849.

Santangelo, G. D. 2018. The impact of FDI in land in agriculture in developing countries on host country food security. Journal of World Business, 53(1): 75-84.

Schneider Electric. 2020a. Schneider sustainability report 2020 Climate contribution. https://sdreport.se.com/en/climate-sdgcontribution. Accessed 13 September 2020.

Schneider Electric. 2020b. Schneider Electric opens its first Smart Distribution Center in India. https://www.se.com/in/en/aboutus/newsroom/news/press-releases/schneider-electric-opensits-first-smart-distribution-center-in-india-

5f3f6c7b56e2d87ecb608550. Accessed 13 September 2020.

Schneider Electric. 2020c. Schneider sustainability report 2020Development. https://sdreport.se.com/en/development-sdgcontribution. Accessed 13 September 2020.

Shah, N. K. 2013. Corporate philanthropy and conflicts of interest in public health: ExxonMobil, Equatorial Guinea, and malaria. Journal of Public Health Policy, 34(1): 121-136.

Shandra, C. L., Shandra, J. M., \& London, B. 2011. World Bank structural adjustment, water, and sanitation: A cross-national analysis of child mortality in Sub-Saharan Africa. Organization \& Environment, 24(2): 107-129.
Shapiro, D., Hobdari, B., \& Oh, C. H. 2018. Natural resources, multinational enterprises and sustainable development. Journal of World Business, 53(1): 1-14.

Sidibe, M. 2020. Marketing meets mission. Harvard Business Review, 98(3): 134-144.

Siegel, J., Pyun, L., \& Cheon, B. Y. 2019. Multinational firms, labor market discrimination, and the capture of outsider's advantage by exploiting the social divide. Administrative Science Quarterly, 64(2): 370-397.

Sinkovics, N., \& Archie-acheampong, J. 2019. The social value creation of MNEs-A literature review across multiple academic fields. Critical Perspectives on International Business, 16(1): 7-46.

Spencer, J. W. 2008. The impact of multinational enterprise strategy on indigenous enterprises: Horizontal spillovers and crowding out in developing countries. Academy of Management Review, 33(2): 341-361.

Spires, A. J. 2011. Organizational homophily in international grantmaking: US-based foundations and their grantees in China. Journal of Civil Society, 7(3): 305-331.

Spires, A. J. 2012. Lessons from abroad: Foreign influences on China's emerging civil society. The China Journal, 68: 125-146.

Srai, J. S., Alinaghian, L. S., \& Kirkwood, D. A. 2013. Understanding sustainable supply network capabilities of multinationals: A capability maturity model approach. Proceedings of the Institution of Mechanical Engineers, Part $b$ : Journal of Engineering Manufacture, 227(4): 595-615.

Strotmann, H., Volkert, J., \& Schmidt, M. 2019. Multinational companies: Can they foster well-being in the eyes of the poor? Results from an empirical case study. International Journal of Corporate Social Responsibility, 4(1): 2.

Surroca, J., Tribó, J. A., \& Zahra, S. A. 2013. Stakeholder pressure on MNEs and the transfer of socially irresponsible practices to subsidiaries. Academy of Management Journal, 56(2): 549-572.

Symeou, P. C., Zyglidopoulos, S., \& Williamson, P. 2018. Internationalization as a driver of the corporate social performance of extractive industry firms. Journal of World Business, 53(1): 27-38.

Tallman, S., \& Yip, G. S. 2009. Strategy and the multinational enterprise. In A. M. Rugman (Ed.), The Oxford handbook of international business: 307-340, (2nd ed.). New York: Oxford University Press.

Teece, D. J. 2014. A dynamic capabilities-based entrepreneurial theory of the multinational enterprise. Journal of International Business Studies, 45(1): 8-37.

Teegen, H., Doh, J. P., \& Vachani, S. 2004. The importance of nongovernmental organizations (NGOs) in global governance and value creation: An international business research agenda. Journal of International Business Studies, 35(6): 463-483.

Tempels, T., Blok, V., \& Verweij, M. 2020. Injustice in foodrelated public health problems: A matter of corporate responsibility. Business Ethics Quarterly, 30(3): 388-413.

Terjesen, S., Aguilera, R., \& Lorenz, R. 2015. Legislating a woman's seat on the board: Institutional factors driving gender quotas for boards of directors. Journal of Business Ethics, 128(2): 233-251.

Tihanyi, L. 2020. From "that's interesting" to "that's important." Academy of Management Journal, 63(2): 329-331.

Toh, S. M., \& Leonardelli, G. J. 2012. Cultural constraints on the emergence of women as leaders. Journal of World Business, 47(4): 604-611.

Uduji, J. I., \& Okolo-Obasi, E. N. 2017. Multinational oil firms' CSR initiatives in Nigeria: The need of rural farmers in host communities. Journal of International Development, 29(3): 308-329.

Uhlenbruck, K., Rodriguez, P., Doh, J., \& Eden, L. 2006. The impact of corruption on entry strategy: Evidence from telecommunication projects in emerging economies. Organization Science, 17(3): 402-414. 
Unilever. 2015. Unilever's UN Sustainable Development Goals. https://www.unilever.com/planet-and-society/sustainabilityreporting-centre/sustainable-development-goals/. Accessed 13 September 2020.

Unilever. 2020. Handwashing for life. https://www.unilever.com/ sustainable-living/improving-health-and-well-being/healthand-hygiene/healthy-handwashing-habits-for-life/. Accessed 13 September 2020.

United Nations. 2000. United Nations Millennium Development Goals. https://www.un.org/millenniumgoals/. Accessed 13 September 2020.

United Nations. 2015. Transforming our world: The 2030 Agenda for sustainable development. https://sustainabledevelopment. un.org/post2015/transformingourworld. Accessed 7 December 2019.

United Nations. 2018. Gender equality: Why it matters. https:// www.un.org/sustainabledevelopment/wp-content/uploads/ 2018/09/Goal-5.pdf. Accessed 13 September 2020.

United Nations. 2019. Guidelines for the use of the SDG logo, including the color wheel and 17 icons. https://www.un.org/ sustainabledevelopment/news/communications-material/. Accessed 13 September 2020.

United Nations. 2020a. Goal 2: Zero hunger. https://www.un. org/sustainabledevelopment/hunger/. Accessed 13 September 2020

United Nations. 2020b. Goal 16: Peace, justice and strong institutions. https://www.un.org/sustainabledevelopment/ peace-justice/. Accessed 13 September 2020.

United Nations Development Programme. 2020a. Goal 4: Quality education. https://www.undp.org/content/undp/en/ home/sustainable-development-goals/goal-4-qualityeducation. Accessed 13 September 2020.

United Nations Development Programme. 2020b. Goal 9: Industrial innovation and infrastructure. https://www.undp. org/content/undp/en/home/sustainable-development-goals/ goal-9-industry-innovation-and-infrastructure/. Accessed 13 September 2020.

United Nations Development Programme. 2020c. Goal 3: Good health and well-being. https://www.undp.org/content/undp/ en/home/sustainable-development-goals/goal-3-goodhealth-and-well-being. Accessed 13 September 2020.

United Nations Environment Programme. 2018. The state of plastics: World Environment Day outlook 2018. http://www. unenvironment.org/resources/report/state-plastics-worldenvironment-day-outlook-2018. Accessed 30 September 2020.

United Nations Environment Programme. 2019. Global resources outlook 2019: Natural resources for the future we want. https:// www.resourcepanel.org/reports/global-resources-outlook. Accessed 28 September 2020.

United Nations Global Compact, \& Accenture. 2019. UN Global Compact-Accenture Strategy 2019 CEO study-The decade to deliver: $A$ call to business action. https://www. unglobalcompact.org/library/5715. Accessed 13 September 2020.

Vaaler, P. M. 2011. Immigrant remittances and the venture investment environment of developing countries. Journal of International Business Studies, 42(9): 1121-1149.

Van Cranenburgh, K., \& Arenas, D. 2014. Strategic and moral dilemmas of corporate philanthropy in developing countries: Heineken in Sub-Saharan Africa. Journal of Business Ethics, 122(3): 523-536.

van Tulder, R., van Wijk, J., \& Kolk, A. 2009. From chain liability to chain responsibility: MNE approaches to implement safety and health codes in international supply chains. Journal of Business Ethics, 85(S2): 399-412.

van Zanten, J. A., \& van Tulder, R. 2018. Multinational enterprises and the Sustainable Development Goals: An institutional approach to corporate engagement. Journal of International Business Policy, 1(3-4): 208-233.
VanSandt, C. V., \& Sud, M. 2012. Poverty alleviation through partnerships: A road less travelled for business, governments, and entrepreneurs. Journal of Business Ethics, 110(3): 321-332.

Verbeke, A., \& Fariborzi, H. 2019. Managerial governance adaptation in the multinational enterprise: In honour of Mira Wilkins. Journal of International Business Studies, 50(8): 1213-1230.

Wei, Y., \& Liu, X. 2006. Productivity spillovers from R\&D, exports and FDI in China's manufacturing sector. Journal of International Business Studies, 37(4): 544-557.

Wettstein, F., Giuliani, E., Santangelo, G. D., \& Stahl, G. K. 2019. International business and human rights: A research agenda. Journal of World Business, 54(1): 54-65.

Wiedmann, T., Lenzen, M., Keyßer, L. T., \& Steinberger, J. K. 2020. Scientists' warning on affluence. Nature Communications, 11(1): 3107.

Wilson, D. C., Velis, C., \& Cheeseman, C. 2006. Role of informal sector recycling in waste management in developing countries. Habitat International, 30(4): 797-808.

Winthrop, R., Bulloch, G., Bhatt, P., \& Wood, A. 2013. Investment in global education: A strategic imperative for business. Brookings Institution. https://www.brookings.edu/ research/investment-in-global-education-a-strategic-imperativefor-business/. Accessed 6 September 2020.

Witte, C., \& Dilyard, J. 2017. Guest editors' introduction to the special issue: The contribution of multinational enterprises to the Sustainable Development Goals. Transnational Corporations, 24(3): 1-8.

Woetzel, J., Madgavkar, A., Ellingrud, K., Labaye, E., Devillard, S., Kutcher, E., Manyika, J., Dobbs, R., \& Krishnan, M. 2015. How advancing women's equality can add $\$ 12$ trillion to global growth. McKinsey \& Company. https://www. mckinsey.com/featured-insights/employment-and-growth/ how-advancing-womens-equality-can-add-12-trillion-to-glo bal-growth. Accessed 13 September 2020.

World Bank. 2020. The World Bank Group works to end poverty. https://www.worldbank.org/en/topic/poverty/overview. Accessed 13 September 2020.

World Wide Fund for Nature. 2014. Living planet report 2014: Species and spaces, people and places. https://www. worldwildlife.org/publications/living-planet-report-2014. Accessed 28 September 2020.

Wu, C., Lawler, J. J., \& Yi, X. 2008. Overt employment discrimination in MNC affiliates: Home-country cultural and institutional effects. Journal of International Business Studies, 39(5): 772-794.

Yach, D. 2008. Food companies and nutrition for better health. Public Health Nutrition, 11(2): 109-111.

Yach, D., Feldman, Z. A., Bradley, D. G., \& Khan, M. 2010. Can the food industry help tackle the growing global burden of undernutrition? American Journal of Public Health, 100(6): 974-980.

Yakovleva, N., \& Vazquez-Brust, D. A. 2018. Multinational mining enterprises and artisanal small-scale miners: From confrontation to cooperation. Journal of World Business, 53(1): 52-62.

Yang, H., Ma, M., Thompson, J. R., \& Flower, R. J. 2018. Waste management, informal recycling, environmental pollution and public health. Journal of Epidemiology and Community Health, 72(3): 237-243.

Zaheer, S. 1995. Overcoming the liability of foreignness. Academy of Management Journal, 38(2): 341-363.

Zhang, J., \& Luo, X. R. 2013. Dared to care: Organizational vulnerability, institutional logics, and $\mathrm{MNCs}^{\prime}$ social responsiveness in emerging markets. Organization Science, 24(6): 1742-1764.

Zhao, M. 2006. Conducting R\&D in countries with weak intellectual property rights protection. Management Science, 52(8): 1185-1199. 


\section{ABOUT THE AUTHORS}

Ivan Montiel is an Associate Professor of Management at the Zicklin School of Business, Baruch College, the City University of New York, USA. He investigates how businesses can tackle grand challenges with a special interest in emerging economies. His work has appeared in top journals including Journal of International Business Studies, Strategic Management Journal, Journal of Business Ethics, and Business \& Society, among others.

Alvaro Cuervo-Cazurra is a Professor of International Business and Strategy at Northeastern University, Boston, USA, and co-editor of Global Strategy Journal. He studies the internationalization of firms, particularly emerging market multinationals; capability upgrading, focusing on technological capabilities; and governance issues, especially state ownership and corruption. He was elected a Fellow of AIB, received an Honorary Doctorate from Copenhagen Business School, and was awarded a PhD from MIT.

Junghoon Park is a PhD Candidate in Management at the Zicklin School of Business, Baruch College, the City University of New York, USA. He explores how firms respond differently to grand challenges faced by society, such as climate change and human health, and their implications for firm performance. He earned an MS in international business from Kyung Hee University.

Raquel Antolín-López is an Associate Professor of Management at the University of Almeria, Spain. She is interested in understanding how entrepreneurs and businesses can tackle sustainability grand challenges. Her research has been published in Technovation, Academy of Management Learning \& Education, and Journal of Business Ethics, among others. She has received several awards, including the AOM best paper award.

Bryan W. Husted is a Professor of Management at the EGADE Business School of the Tecnologico de Monterrey, Mexico, where he coordinates the research group in social innovation. His current research focuses on corporate sustainability in emerging markets. His work has appeared in such journals as Journal of International Business Studies, Journal of Management, Organization Science, and Strategic Management Journal, among others.

Publisher's Note Springer Nature remains neutral with regard to jurisdictional claims in published maps and institutional affiliations.

Accepted by Alain Verbeke, Editor-in-Chief, 10 April 2021. This article has been with the authors for two revisions. 